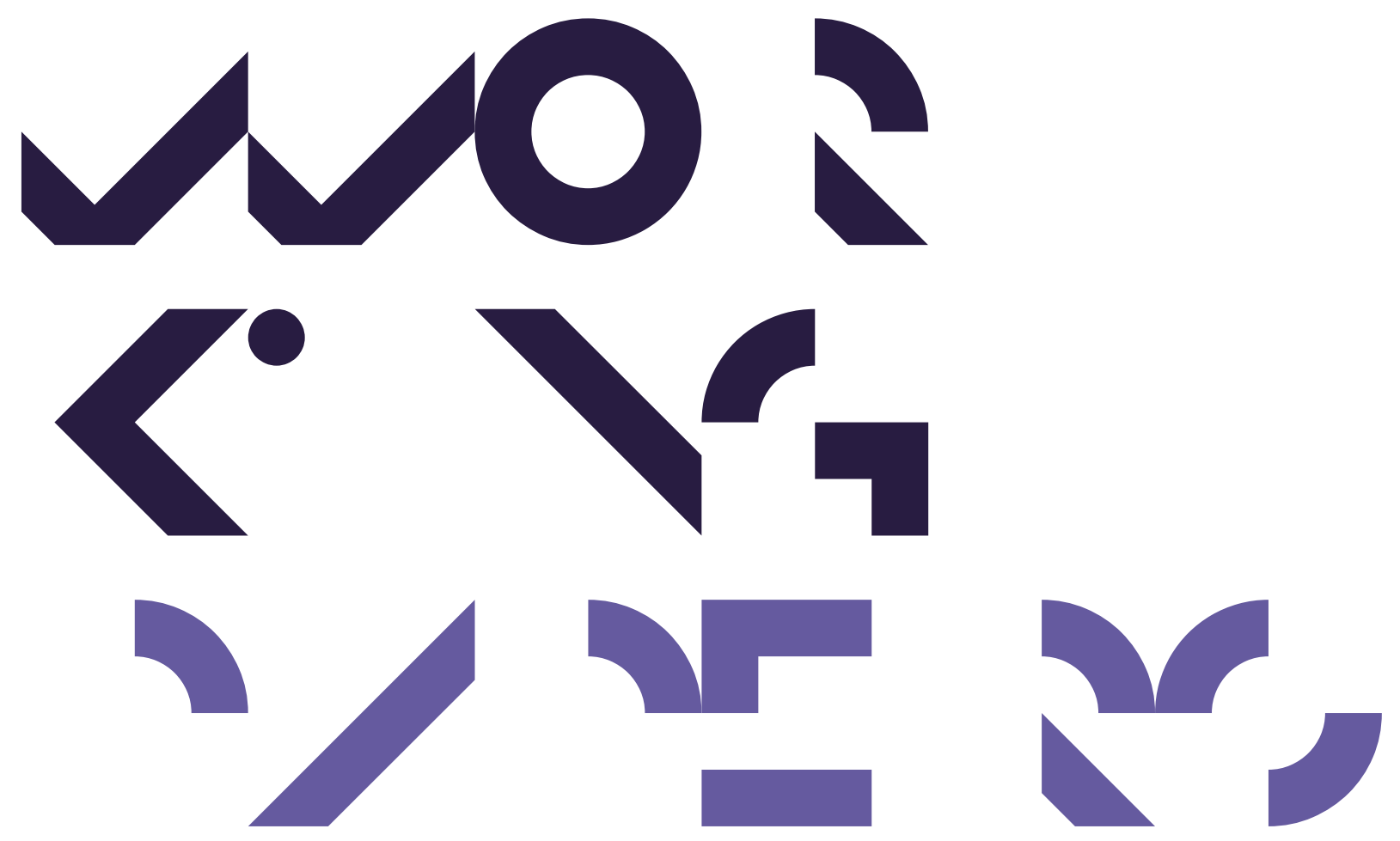

Economics Working Papers

2013-18

Do Social Rights Affect Social Outcomes?

Christian Bjørnskov and Jacob Mchangama 


\title{
Do Social Rights Affect Social Outcomes?
}

\section{Christian Bjørnskov*}

\author{
Aarhus University and Center for Political Studies
}

\section{Jacob Mchangama}

\section{The Freedom Rights Project and Center for Political Studies}

September 9, 2013

Abstract: While the United Nations and NGOs are pushing for global judicialization of economic, social and cultural rights (ESCRs), little is known of their consequences. We provide evidence of the effects of introducing three types of ESCRs into the constitution: the rights to education, health and social security. Employing a large panel covering annual data from 160 countries in the period 19602010, we find no robust evidence of positive effects of ESCRs. We do, however, document adverse medium-term effects on education and inflation.

Keywords: Human rights, human development, constitutional political economy JEL-classifications: K19, H11 og O11

\footnotetext{
* Mchangama: Center for Political Studies, Landgreven 3, DK-1301 Copenhagen K, Denmark; E-mail: . Bjørnskov: Aarhus University, Department of Economics and Business, Fuglesangs Allé 4, DK-8210 Aarhus V, Denmark. Email: chbj@asb.dk. Mchangama is also Director of the Freedom Rights Project. Aoife Hegarty, Lise Reuss Muff, Kristoffer Agner Gredsted and Rasmus Rødby Kristiansen provided excellent research assistance. We are grateful for comments from Niclas Berggren, Anna Brüderle, Martin Gassebner, Jerg Gutman, Pierre-Guillaume Méon, Martin Paldam, Josh Tucker, Anna Welander and participants of the 2013 Public Choice Meetings (New Orleans), the 2013 Beyond Basic Questions workshop (Luzern) and the 2013 ISNIE conference (Florence). All remaining errors are naturally ours.
} 


\section{Introduction}

On 10 December 2008, the United Nation's General Assembly adopted an optional protocol to the International Covenant on Economic, Social and Cultural Rights ("ICESCR"), which was opened for signature and ratification on 24 September 2009 (protocol A/RES/63/117). The optional protocol (hereafter "the Protocol") allows ratifying state parties to the ICESCR to recognize the competence of the Committee on Economic, Social and Cultural Rights (hereafter "The Committee") to receive and consider communications from individuals alleging that their rights under the ICESCR have been violated. The adoption of the Protocol marks the most tangible step towards formalizing the "indivisibility" of all international human rights, a concept formally proclaimed in the "Vienna Declaration and Programme of Action" adopted at the World Conference on Human Rights in 1993. The indivisibility of all human rights has since been adopted by the UN, where this concept forms an integral part of all UN human rights related activities. The adoption of the Protocol was preceded by a decades-long discussion of the so-called "justiciability" of ESCRs; i.e. whether such rights were capable of being ruled upon by courts in the same manner as civil and political rights (CPRs), which have long been the subject of judicial application at both the domestic and international level.

A key factor in paving the way for the acceptance of individual applications in the sphere of ESCRs at the international level has been the development towards adopting and including such rights in national constitutions, as well as a greater willingness by national courts to engage in judicial review of these rights. To date, some 75 states from most continents have implemented a comprehensive number of ESCRs in their constitution; 37 of those states have made some or all of these rights justiciable (cf., Jung and Rosevear, 2011). Given the heated discussions surrounding the drafting of the Protocol and the limited number of signatures and ratifications thereof (at the time of writing the Protocol has only just received the prerequisite 10 ratifications in order to enter into force, which happened on 5 May 2013, three months after Uruguay became the $10^{\text {th }}$ state to ratify the Protocol) the issue of justiciability is unlikely to be finally settled in the immediate future. 
However, while there has been a long debate on the issue of justiciability of ESCRs, there has been almost no focus on whether adopting these rights in national constitutions actually delivers the underlying goods promised by these rights. In other words, there is no tangible, empirical basis for claiming that the introduction of such rights - whether at the national or international level - makes any difference in the desired direction. One reason for this absence may be that the question is controversial and discussions tend to be politicized. Previous studies relying on simplistic methods failed to find any effects on health indicators of ratifying human rights treatises, but still concluded that the right to health is important in the longer run (e.g. Palmer et al., 2009). Even this conclusion has been received unfavorably, as Getgen and Meier (2009) argue that Palmer et al. are too skeptical of ECSRs and that one ought to explore all the potential causal pathways connecting ESCRs and outcomes. Conversely, Chauffour's (2011) finding that CPRs are strongly associated with human development received relatively bad press.

In this paper, we therefore revisit the question whether the introduction of ESCRs affects economic, social and cultural development. We do so by surveying the constitutions of 188 states using the website of the World Intellectual Property Organization as our primary source, supplementing it with information from a number of other sources. Information on whether or not the economic or social rights included in the identified constitutions are justiciable derives from the "TIESR Dataset" by the Toronto Initiative for Economic and Social Rights. Doing so allows us to build a unique dataset covering the years between 1960 and 2010 during which we trace the constitutional status of three main social rights: the right to health, education and social security (which rights are also protected at the international level in the ICESCR).

We necessarily focus exclusively on the de jure status of the selected ESCRs, although we note the somewhat blurry distinction between de jure and de facto implementation of such rights in national legislation. To anticipate our findings, a set of error-correction panel estimates with country fixed effects show that the introduction of the aforementioned ESCR do not, in general, lead to robustly 
positive effects on long-term social development. We do, however, document a strongly negative medium-term effect on education, as well as an undesirable and robustly negative medium-term increase of inflation following the introduction of social rights. When focusing on health outcomes, findings are more mixed with weakly positive effects of non-justiciable rights on immunization rates but detrimental effects of the right to health on child mortality.

After describing the quantitative data in the second section of the paper, we explore how the introduction of the ESCRs affects the actual situation in these areas, as well as the overall human rights situation and the quality of the institutional framework. We conclude by discussing the political and social importance of our findings.

\section{Theoretical perspectives on ESCRs}

We first turn to the entirely theoretical mechanisms that may connect the introduction of ESCRs to actual social outcomes. Here, as in the literature on property rights, it is entirely possible and - as we shall argue in a legal outline of the concept - quite likely that de jure rights are not enforced (Feld and Voigt, 2003; Libman, 2010; Bjørnskov, 2011). Likewise, in an economic outline of the concept, we outline a set of potentially offsetting consequences that may yield undesired outcomes.

\subsection{Judicial perspectives on ESCRs}

According to the United Nations, all human rights are 'indivisible', and the international community "must treat human rights globally in a fair and equal manner, on the same footing, and with the same emphasis" (UN General Assembly, Vienna Declaration and Programme of Action, 12 July 1993, UN Doc. A/CONF.157/23 and UN General Assembly, 2005 World Summit Outcome Document, 24 October 2005, UN Doc. A/RES/60/1). Similarly, a number of NGOs and academics have in recent years argued that human rights are indivisible and should be implemented as a single policy measure (e.g., Jayawickrama, 2008). As we briefly outline in the following, from a legal-institutional perspective, this 
may be a questionable assumption. Authors such as Dennis and Stewart (2004) and Whelan (2010) have argued that when it comes to justiciability the so-called indivisibility of all human rights is to a considerable degree a revisionist idea developed by academics, human rights institutions and UN Treaty bodies, without support in existing human rights law.

Likewise, the empirical literature indicates that human rights are in fact statistically divisible, and thus in practice not implemented as an indivisible 'package'. Nikkel (2008) states, "it appears likely that the United Nations statements about indivisibility are broad overstatements of more modest truths". When, for example, focusing on core civil and political human rights, there is a clear association between different rights that may indeed in the long run tend to be indivisible. Although the causal mechanisms are still up for discussion, political rights and property rights protection are strongly correlated (e.g. Friedman, 1962; Blume and Voigt, 2007; Rode and Gwartney, 2012; Voigt, 2012). As Lawson and Clark (2010) note, there is considerable empirical support for the Hayek-Friedman theory that political rights in the form of democracy and civil liberties are sustained in the long run by concepts such as the rule of law and strong judicial institutions. In particular, there are virtually no examples of democratically stable countries without reasonably independent and functioning judicial institutions. Conversely, whereas, at least some CPRs do tend to be correlated, the same is not likely to be the case for ESCRs.

The Universal Declaration on Human Rights (UDHR) was adopted in 1948. Of the 30 articles in the UDHR articles 1-21 are devoted to CPRs, whereas 22-29 deal with ESCRs as their subject matter. However, it is crucial to note that Article 22 of the UDHR states that

Everyone, as a member of society, has the right to social security and is entitled to realization, through national effort and international co-operation and in accordance with the organization and resources of each State, of the economic, social and cultural rights indispensable for his dignity and the free development of his personality. 
This so-called umbrella provision qualifies the nature of the subsequent ESCRs in comparison with the preceding CPRs. The umbrella provision in Article 22 was inserted at the insistence of Rene Cassin, one of the principle "Founding Fathers" of the UDHR, based on his view that "Rights to life and liberty were unconditional. The realization of economic and social rights, on the other hand, involved material assistance on the part of the State" (UN Doc. E/CN.4/SR.72 of 24 June 1948). When the UN adopted legally binding conventions it was ultimately decided to split CPRs and ESCRs into the ICCPR and the ICESCR respectively. The decision to adopt two separate covenants has often been described as a result of Cold War rivalries. States including the United States, Belgium and New Zealand pushed for the bifurcation of the covenants, arguing that CPRs were far more readily implementable, while the realization of ESCRs was a progressive endeavor (Amos, 2011). Britain went as far questioning whether or not the latter category of rights was even "legally enforceable" seeing as they were "purely relative conceptions" (UN Doc. A/C.3/SR.390, 251 of 16 January 1952).

While the ideological climate of the Cold War played an important role in the negotiations surrounding the UDHR, ICCPR and ICESCR, several nominal supporters of ESCRs accepted that these were not indivisible from CPRs when it came to the enforcement thereof (Amos, 2011). The chairman of the Commission on Human Rights Eleanor Roosevelt justified the separation of the two categories of rights based on the premise that ESCRs were "not justiciable" and that "the basic differences between civil and political rights and economic, social, and cultural rights warrant this division into two covenants" (Roosevelt, 1951). The difference between CPRs and ESCRs is highlighted in the stark difference of the wording of ICCPR and ICESCR respectively. Article 2 of the ICCPR obliges states "to respect and to ensure to all individuals within its territory and subject to its jurisdiction the rights recognized" in the covenant. In addition, its first optional protocol provides a mechanism for individual complaints of violations. Article 2 of the ICESCR on the other hand obliges states "to take steps, individually and through international assistance and co-operation, especially economic and technical, to the maximum of its available resources, with a view to achieving 
progressively the full realization of the rights recognized in the present Covenant by all appropriate means, including particularly the adoption of legislative measures".

Whereas an optional protocol has allowed individual complaints under the ICCPR since 1976, an optional protocol allowing complaints under the ICESCR was not adopted until 2008 and only entered into force in May 2013. Whereas the relatively poorly enforced African Charter on Human and Peoples' Rights does include ESCRs (as well as collective rights and duties) regional human rights protection systems such as the European Convention on Human Rights (ECHR) and the American Convention on Human Right (ACHR) focus overwhelmingly on CPRs. However, both the European Court of Human Rights (ECtHR) and the Inter-American Court of Human Rights (IACtHR) have at times blurred the lines between these categories through dynamic interpretation of the respective conventions. For example, in the case of Kjartan Asmundsson v. Iceland (App. No. 60669/00, judgment of 12 October 2004), the ECtHR found a violation of the right to property (Article 1 of Protocol No. 1), where the applicant was no longer entitled to receive disability benefit.

At the Inter-American level, the IACtHR held in Case of Children's rehabilitation vs. Paraguay (Judgment of Sept. 2, 2004 [Ser. C] No. 112) that inherent in the right to life (Article 4 ACHR) was the right to live a "dignified life". In this regard, the Court maintained that certain basic ESCRs such as health and education were also covered by Article 4, with heightened state obligations owed to prison detainees and other others persons unable to sustain themselves (Langford, 2008, p. 390). Formally, the EU's Charter on Fundamental Rights, which became legally binding as part of the Lisbon Treaty, can be seen as committed to indivisibility as it includes both CPRs and ESCRs. However, it is clear that many of the ESCRs are qualified in nature when compared to the CPRs. For instance, Article 6 of the Charter states that "Everyone has the right to liberty and security of person", whereas Article 34 states that "the Union recognizes and respects the entitlement to social security benefits and social....in accordance with the rules laid down by Community law and national laws and practices". 
While some 75 countries have adopted constitutions including ESCRs, only 37 have made some or all of these justiciable. Langford (2008) shows that courts in countries such as Columbia, Venezuela and Brazil have attached significant weight to constitutionally protected ESCRs. South Africa's constitution is often hailed as a progressive example of indivisibility due to the inclusion of explicitly justiciable ESCRs (Mbazira, 2009). The practice of the South African Constitutional Court, however, does distinguish between CPRs and ESCRs, making the latter subject to a "reasonableness" test, and rejecting that these rights confer an individually enforceable right (Mbazira, 2009; Langford, 2008, pp. 82-86, 90-91). Yet, while there seems to be a global tendency of courts to be increasingly willing to adjudicate on ESCRs, full justiciability on par with CPRs is still largely the exception and several liberal democracies including Denmark, the US, Great Britain, Poland, the Netherlands, Canada, Ireland and Switzerland still tend to regard most ESCRs as primarily consisting of policy goals that are insufficiently precise in nature to be justiciable in the same manner as CPRs (Howard-Hessman et al., 2006; Langford, 2009; Jackman, 2010). These countries also insist, inter alia, that justiciable ESCRs would conflict with the separation of powers by affording courts the competence to decide on matters of social and economic policy involving competing interests and budgetary allocations that are the prerogative of elected parliaments and governments instead of courts or quasi-judicial bodies (Ibid). When the Protocol was being debated in the Third Committee of the United Nation's General Assembly, Denmark, a liberal democracy with a welfare system based on a commitment to substantial levels of redistribution, made the following statement:

"the majority of the rights in the Covenant do not carry immediate legal effect. Considering the vague nature of the rights and the principle of progressive realization, Denmark firmly believes that the majority of the rights in the Covenant is insufficiently judiciable and therefore less suited to form the basis of an individual complaints mechanism. Moreover, due to the vague and broad nature of the rights in the Covenant, Denmark fears that there is a sincere risk that the Committee will end up both 
functioning as a legislator $[. .$.$] and determining the allocation of states parities' allocation$ of $[\ldots]$ resources $[\ldots]$. Denmark finds both scenarios unacceptable as we place great importance on the fact that allocation of resources [...] is a national matter, which is the responsibility and prerogative for national, democratic institutions with direct, popular legitimacy." (Explanation of Position of Denmark at the 63th session of the United Nations General Assembly).

Accordingly, the - nominal - international consensus on indivisibility at the UN and among human rights organizations and institutions cannot be said to reflect an international consensus when looking at state practice and international human rights standards. And while proponents of indivisibility and the justiciability of ESCRs can point to impressive gains in terms of significant developments at the academic, institutional and jurisprudential level, the legal debate on the status of ESCRs is far from settled.

\subsection{Economic perspectives on ESCRs}

It is not only arguments over perceived lack of judicial clarity that surrounds the question of how to implement ESCRs, the issue is also far from unambiguous when viewed from a political-economic angle. Only a strongly partial analysis is likely to lead to an unambiguous, positive outcome while a fuller general equilibrium analysis includes offsetting consequences.

An obvious economic problem for example arises when access to certain health services is deemed to be a human right. In this situation, private health clinics will be legally unable to charge clients for providing the service when they are given a constitutionally protected right to such services. The only partial exception would arise if health clinics were legally able to bundle protected services with other, complementary health services not covered by the set of constitutionally recognized services. Likewise, including the service in health insurance schemes would make little sense, since it is available without charge to everyone, regardless of their insurance status. In such a scenario, a rational - 
and legal - strategy to limit losses would be to cease providing the service altogether. An enforceable human right to access such services is therefore likely to cause the services to disappear from a private market. The ultimate, logical consequence is a de facto nationalization of the particular market segment, either through public production at publicly owned hospitals or full public financing, or an acceptance of a clearly adverse effect of the introduction of this ESCR.

Second, even though the introduction of ESCRs may have positive or neutral long-run consequences, it may entail transition costs that in the medium run worsen the status of health, education or other social indicators. These costs may be most immediately visible in the cases of education and ongoing efforts to directly reduce the plight of low-income families. The basic problem creating transition costs when introducing rights is that of politically redirecting resources towards aims that are covered by ESCRs. Introducing a right to education may thus entail either substantially larger intakes of students or, given that education is a right and as such not a service for which schools can charge a fee, a loss of income associated with those covered by the right. This may cause a legallyobligated reallocation of resources and efforts towards new pupils, leaving those already in the schooling system with substantially less means and potentially failed education. In other words, there may be a cost specific to particular age cohorts associated with the introduction of education rights.

In both cases, any argument in favor of positive effects must rest on an assumption of the existence of major market failures in the markets for education, health services or other markets that more than outweigh the likely government failures that might arguably arise from introducing ESCRs (cf., Mueller, 2003). Otherwise, the introduction of such rights may lead to a permanent misallocation of resources and thus a net loss of welfare in the long run, as well as a potential political lock-in of part of the resource allocation that could be harmful to subsequent development. Whether the government produces or merely finances the access to, e.g., free education and health services and provides substantial social security, (thereby attempting to close the gap between rich and poor as stressed by numerous reports from UN special rapporteurs), government expenditures are likely to be permanently 
larger if no other expenditures are cut. In the short to medium run, the introduction of ESCRs thus seems to imply what amounts to rather strongly expansionary fiscal policy, which could induce economic problems similar to Dutch Disease and voracity effects (e.g., Tornell and Lane, 1999; Remmer, 2004; Rajan and Subramanian, 2011). As such, one might expect that part of the economic effects of the introduction of ESCRs can be observed as rising inflation rates and subsequent structural changes.

A final potential problem is that the introduction of such rights comes with the risk of undermining other human rights, not least civil liberties. One could indeed argue that ESCRs were defined to be inimical to classical negative rights in order to give the group of countries originally pushing for their introduction - primarily the communist bloc and a group of non-democratic Latin American states - some degree of apparent bargaining power in international human rights fora (cf. Vreeland, 2008). In the extreme case of nationalization of health and education, private property rights must almost necessarily be violated for a time. Likewise, except in the case of governments with very substantial resources (e.g. oil states), other ESCRs such as the right to housing or specific living standards will entail either outright expropriation of resources or substantial and highly progressive taxation. All situations will likely entail weakened judicial institutions that are brought under political control.

Yet, such institutions, and in particular their political independence, are central to the long-run economic and democratic development of countries (North, 1990; Rodrik et al., 2004). Conversely, economic development and globalization, which social commentators often claim can be directly harmful to human rights in developing countries, seems to lead to beneficial social outcomes and increased respect for central human rights in the long run (Cingranelli and Richards, 1999; Richards et 
al., 2001; Bergh and Nilsson, 2010; Dreher et al., 2012). ${ }^{1}$ Constitutional provisions, on the contrary, are often found to be of insignificant relevance to de facto government and institutional behavior and economic or political outcomes (e.g., Feld and Voigt, 2003).

As such, there are several reasons from legal and political economic theory that indicate that the introduction of ESCRs in the constitution could be either irrelevant to social development, mere window-dressing or directly counterproductive. In the following, we therefore turn to data from the last half-century in order to estimate the consequences of their introduction.

\section{Data and empirical strategy}

Our main variables in the following are three sets of two dummies each that capture whether or not a country has implemented ESCRs, either through constitutional amendment or by constitutional reinterpretation. In this regard, one dummy measures whether this implementation has in fact happened, while the other is conditional on this right being made justiciable. We build this dataset by surveying the constitutions of 188 sovereign states using the website of the World Intellectual Property Organization as our primary source (WIPO, 2012). The constitutions thus identified were then checked against the constitutions available via the Constitution Finder maintained by the T.C. Williams School of Law at Richmond University ${ }^{2}$, the Right to Education Project ${ }^{3}$, the International Constitutional Law Project ${ }^{4}$,

1 An additional question frequently asked in recent studies in international political economy is why countries join international agreements. Countries such as Sudan, China and Libya have, for example, served on the United Nations Human Rights Council despite their grave human rights records. The question is whether countries when joining are aiming at abiding by the convention or if they rather join to avoid international criticism when breaking the convention (Vreeland, 2008). We leave this question in the context of introducing ESCRs to future research.

2 Available at http://confinder.richmond.edu/

${ }^{3}$ Available at http://www.right-to-education.org/country-node/286/country-constitutional

${ }^{4}$ Available at http://www.servat.unibe.ch/icl/ 
the Library of Congress ${ }^{5}$, the World Legal Information Institute ${ }^{6}$ and the Toronto Initiative for Economic and Social Rights ${ }^{7}$. In some cases, in regard to the content of former versions of constitutions, however, resort was had to simply using web search engines to locate the constitutions.

The difficult part of setting up the data is, as mentioned in the introduction, how to code countries' legal adherence to ESCRs, i.e. whether or not the constitutional rights are enforced. Whether the ESCRs included in the identified constitutions are justiciable cannot be ascertained simply by resorting to the wording of the relevant rights, as the issue of justiciability will often depend on the approach and interpretation of national courts. The basis for our basic coding thus follows the TIESR in that specific ESCRs need to be mentioned explicitly in the constitution to be counted as a right. As such, assessing the existence of de jure rights is simple in most cases, and the introduction of rights can be precisely coded as it follows other constitutional changes. The Soviet Constitution of 1918 for example included the right to education while the right to health and social security were added in the 1936 amendment. Furthermore, we note that this constitution was de facto effective in all countries emerging from the Soviet Union until they implemented their own constitutions. In all countries that used to be part of the Soviet Union, we therefore code social rights according to the Soviet Constitution of 1936 until the implementation of a new constitution. Likewise, in formerly Yugoslavian states, we use the Yugoslavian Constitution as basis until a country implemented a new constitution.

We follow Jung (2011) and Jung and Rosevear (2011) in coding whether or not constitutional provisions for ESCRs are de facto justiciable or not. Their work is subsumed in the TIESR dataset maintained at the Toronto Initiative for Economic and Social Rights, which assesses the justiciability of ESCRs in the constitutions of 136 predominantly non-Western nations. As such, we draw a sharp

\footnotetext{
${ }^{5}$ Available at http://www.loc.gov/law/help/guide/nations.php

${ }^{6}$ Available at http://www.worldlii.org/countries.html

${ }^{7}$ Available at http://www.tiesr.org/data.html
} 
distinction between whether ESCRs are introduced into the constitution, but not applicable in actual legal cases, or if such rights can be specifically relied on in cases against the state.

Our main dependent variables are chosen to capture the primary intended consequences of introducing the selected ESCRs: population health, education, and income inequality. To measure health, we follow a long line of literature in using life expectancy, which we get from the World Development Indicators (World Bank, 2012). Education is proxied by the average length of schooling among people over the age of 25 from the Barro and Lee (in press) dataset. As the intended consequences of rights to social security are aimed at increasing the relative position of poor segments of society, we use net (post-tax, post-transfer) income inequality. We get these data from the large, internationally comparable dataset documented in Solt (2009) that also provides a market income (pretax) inequality measure.

We supplement these main variables with a set of alternative measures. For health, we also use immunization rates (measles, diphtheria, BCG and polio) and child mortality rates (aged under 5), which we get from WHO (2012). A particular health measure, child mortality, is known to correlate strongly with absolute poverty and therefore provides an alternative outcome measure supposedly affected by the right to social security. For education, we supplement our main measure with primary and secondary school completion rates from Barro and Lee (in press). Finally, for social security, we use market income inequality, based on pre-tax and pre-transfer income, from Solt (2009).

Our other variables are standard in the literature on economic and human development and are closely associated with the intentions of ESCRs. We add economic development, proxied by the purchasing power adjusted GDP per capita from the Penn World Tables, Mark 7 (Heston et al., 2010). From the same source, we add openness to trade as a share of GDP and the logarithm to population size. All estimates also include the age dependency ratio, defined as the share of the population outside of the working age (15-64 years old), and a dummy for whether or not the incumbent government of a 
country is either communist or unreformed socialist. We follow most of the literature by employing the Polity IV measure of democracy in all estimates (Marshall and Jaggers, 2010).

As in most panel applications, we first ensure that our main data are non-stationary. If not, all results in the following could in principle be spurious. Fischer's test for unit roots, as developed by Maddala and Wu (1999) indeed suggests that our main data tend to be stationary, which would imply that regressions in levels might yield seriously biased results. In all regressions in the following, our dependent variables are therefore all in first differences. As we include a full set of annual / five-year period fixed effects and country fixed effects in all estimates in the following, all country-specific longrun trends due to, e.g., geography or climate are effectively controlled for.

As such, we employ an error-correction model to estimate the effects of implementing ESCRs (ECM, de Boef and Keele, 2008). The model in (1) has the benefit of allowing us to estimate both short-run and long-run (equilibrium) effects of changes to the human rights regime. In all regressions, $Z$ is the outcome variable, $R$ either a de jure or de facto ESCRs indicator, $X$ is a vector of control variables, $I$ is a set of country fixed effects and $T$ a set of period dummies, and $\varepsilon$ an error term assumed to be iid.

$$
\Delta \mathrm{Z}_{\mathrm{i}, \mathrm{t}}=\alpha_{0}+\alpha_{1} \mathrm{Z}_{\mathrm{i}, \mathrm{t}-1}+\beta_{0} \mathrm{X}_{\mathrm{i}, \mathrm{t}-1} \beta_{1} \Delta \mathrm{X}_{\mathrm{t}, \mathrm{t}}+\gamma_{0} \mathrm{R}_{\mathrm{i}, \mathrm{t}}+\gamma_{1} \Delta \mathrm{R}_{\mathrm{i}, \mathrm{t}-1}+\eta \mathrm{I}_{\mathrm{t}}+\mathrm{v}_{\mathrm{i}} \mathrm{T}+\varepsilon
$$

The combination of ECM and country fixed effects means that identification derives from deviations from country-specific long-run trends. This implies that our results are robust to simple endogeneity concerns. Estimation in levels would be problematic if, for example, countries implement rights when they reach a state at which they can either finance the effective enforcement of such rights, or that the underlying problems supposedly alleviated by the introduction of ESCRs were becoming sufficiently minor. In such cases, the non-random timing of introduction would cause findings to suffer from endogeneity bias. However, with identification deriving from long-run trends, this type of endogeneity bias is not an issue, as systematically timed introduction of rights is not likely to reflect a 
shift of the medium or long-run trend. Any causal effect of such rights, on the other hand, ought to be visible as a trend shift. ${ }^{8}$

We employ two different strategies in order to alleviate another potentially important problem. Employing the annual, short-run variation implies that we are running the risk of identifying spurious effects due to two possible complications. First, some countries may have an incentive to misreport actual health and education statistics if these policy areas are politically salient, which they arguably must be around the time that rights are implemented. Second, organizations delivering international statistics, not least health statistics, are de facto publishing estimates of future outcomes. If they expect ESCRs to have positive effects, these expectations may thereby show up in the data as spurious effects. Both types of problems would show up in the data as a temporary increase in either health or education indicators.

Second, as we can be sure that any truly short-run effects are entirely spurious - population health logically cannot improve significantly within one or two years - we therefore repeat all analyses with annual data using five-year samples in which any spurious short-run effects are likely to be washed out. This also takes care of problems of statistical noise arising from short-run J-curve adaptation patterns or staggered political responses to constitutional change. In the five-year estimates, the identified immediate effects occur in the medium run while equilibrium effects can readily be interpreted as true long-run effects. When annual data are available, we correct all results for an estimated degree of first-order autocorrelation that is likely to bias both annual estimates as well as fiveyear estimates in which the use of overlapping periods create autocorrelation by construction.

\footnotetext{
${ }^{8}$ Ideally, we would want to be able to ascertain that the main findings in the following are unbiased, using an instrumental variables approach. However, it is well-known that identifying valid, time-variant instruments for constitutional choices is a formidable challenge. We have been unable to find any variable or set of variables that provided exogenous identification.
} 
4. Do ESCRs cause actual improvements?

We begin by exploring the simple averages across 179 countries for which we have data on constitutional rights and data on aspects of health, education or income inequality. As such, we repeat the simple exercise in Palmer et al. (2009). Taking averages of the period 2005-2010, we first observe in Figure 1 that countries without the right to health or education tend to register neither better nor worse outcomes than countries with those rights: average life expectancy in countries without the right to health was 69.5 years but 67.9 years in countries that do recognize this right $(\mathrm{p}<.32)$. Conversely, average educational length in countries without a right to education was 8.8 years while it was 7.4 years in countries that do recognize such a right $(\mathrm{p}<.01)$. Income inequality does not differ between countries with and without the right to social security, as the average net income Gini in the groups are 38.3 and 38.2, respectively $(\mathrm{p}<.94)$. The figure also shows that countries with these rights tend to have smaller government expenditures and substantially more inflation.

\section{Insert Figure 1 about here}

However, countries that have introduced ESCRs are not comparable to those with no rights. The figure indicates that developing and middle-income countries are more likely to have introduced ESCRs; countries with no such rights are typically approximately $68 \%$ richer than countries with some or all of these rights. This difference obviously means that one cannot simply compare average outcomes across human rights regimes. In the following, we therefore identify any effects of ESCRs through their introduction, controlling for a number of other factors as well as time-invariant countryspecific factors.

\subsection{Health}

We first employ the dataset to estimate the health consequences of introducing health-related rights. We use life expectancy as the preferred standard indicator of population health. In Table 3a, we employ 
the full annual observations, thus enabling us to identify year-to-year changes - which we should logically not observe - and longer-run effects.

\section{Insert Table 3 a about here}

We first find significant positive long-run effects of changes to the age structure, introducing democracy, communism, and openness to trade, and negative effects of population growth. Surprisingly, we also find what appears to be a negative long-run effect of economic growth. In addition, we note that the convergence effect is relatively weak, again surprisingly suggesting that the error-correction multiplier is very small. Most importantly, with respect to health rights, we find no evidence of effects of simply introducing such rights. Employing the annual variation, we also find no significant effects of making health rights justiciable.

However, the long run in these estimates starts after one year, which represents a problem for identifying true long-run consequences. In Table 3b, we therefore repeat the estimates, but employ overlapping five-year periods. We only report the lagged dependent variable and the estimates of the rights variables, although we note that the control variables in general exhibit similar results.

\section{Insert Table $3 b$ about here}

The shift to longer periods has two effects: first, it makes the implied multiplier substantially larger; and second, the effects of introducing health rights become significant in the full sample, although they remain insignificant in the sample of relatively poor countries, defined by observations with a PPP GDP per capita below 14,000 USD. In Appendix Tables A1a and b, we nevertheless find that this estimate is not robust, but turns insignificant if either one of certain influential countries, most clearly El Salvador and Uruguay, are excluded from the sample.

In Tables $4 \mathrm{a}$ and $4 \mathrm{~b}$, we employ a more direct measure of health interventions than life expectancy: the average immunization rate of measles, diphtheria, BCG and polio. The control

\footnotetext{
${ }^{9}$ The exception is that growth becomes significantly positive when we focus on five-year periods.
} 
variables in the annual observations in Table 4 a show a similar pattern as those in Table 3a, with richer countries and communist regimes experiencing slower improvements, and some evidence of effects of population size. With respect to the introduction of health rights, we find only fragile support for any effects in the full sample and no evidence in the poor sample.

\section{Insert Table 4 a about here}

\section{Insert Table $4 b$ about here}

However, when extending the time horizon to five-year periods, we observe significantly positive effects of the introduction of health rights. These effects, as documented in the appendix, are nevertheless again fragile to excluding single countries, as the exclusion of e.g. Djibouti or El Salvador renders the introduction of health rights insignificant, and the effects of justiciable rights seem to be driven entirely by a few Latin American countries. Overall, we thus find some indications but no robust evidence that the introduction of a right to health has effects on objective indicators or population health. Whatever significant results we find are clearly driven by very few outlier observations.

\subsection{Education}

We next turn our attention to education, which necessitates that we focus exclusively on five-year periods in Table 5. We again find a negative effect of the lagged dependent, suggesting an errorcorrection multiplier slightly above 1 . We also find negative effects of changes to the age structure, short-run effects of becoming communist in developing countries and some evidence of positive longrun effects of GDP in relatively poor countries.

\section{Insert Table 5 about here}

However, with respect to our main variables, we find no evidence of long-run effects (further than five years) and rather robust evidence of negative short-to-medium-run effects of introducing rights to education. These negative effects hold, regardless of whether they are justiciable or not, and seem mainly driven by developing countries, as the estimate tends to increase when deleting more 
developed countries from the sample. In Appendix Table A3, we document that this effect is robust to deleting single countries. ${ }^{10}$ Contrary to health rights, the introduction of a right to education thus seems to be associated with substantial negative medium-run consequences.

\subsection{Social security}

Third, in Table 6a we test whether there are significant redistributive effects of introducing rights to social security. We here add squared terms of GDP per capita and democracy to account for economic and political Kuznets curves (cf., Chong, 2004; Bjørnskov, 2010). We find considerable evidence for both types, with top points around low to intermediate levels of income and democracy. We also find clear long-run effects of turning communist. Conversely, we find no effects of population size or openness to trade.

\section{Insert Table 6 a about here}

With respect to the introduction of rights to social security, we find no evidence of any short- or medium-run increases in net inequality. As we show in Table $6 \mathrm{~b}$, the positive but insignificant short-run effects in Table 6a turn weakly significant in a five-year panel. However, these findings do not generalize to justiciable rights and turn out to be less than robust in the appendix. Yet, in Tables $6 \mathrm{c}$ and 6d, where we repeat the estimates with market Ginis, i.e. measures of pre-redistribution income inequality, we find robust evidence of short-run increases in inequality after non-justiciable rights are introduced but again no clear effects within a five-year perspective.

Insert Table $6 b$ about here

Insert Table $6 c$ about here

\footnotetext{
${ }^{10}$ In further tests (not shown), we use primary and secondary school completion rates instead of the average rate of schooling. Alternative measures from Barro and Lee (in press) exhibit very similar overall results, with no evidence of positive effects of education rights and comparable negative medium-run effects of introducing rights.
} 


\section{Insert Table $6 d$ about here}

Yet, part of the discussion of ESCRs is not merely about the distribution of income, but also about alleviation of deep poverty. We prefer not to use direct estimates of poverty, such as the share of the population living below 1.25 USD per day, as such estimates are highly imprecise and sensitive to non-market sources of income. Instead, we follow recent practice and use child mortality rates as a more direct outcome measure of deep poverty.

In Table 7, we report the main results of using child mortality as an alternative poverty indicator within five-tear periods. While we find no evidence for effects of introducing health rights per se, the introduction of justiciable health rights in developing countries seems to be associated with a subsequent, significant increase in child mortality. In other words, we identify an adverse, disruptive medium-run effect of the introduction of justiciable rights to health services that fortunately washes out in the long run. Although the size of the point estimate proves to be particularly sensitive to the introduction of South Africa and Mozambique, as we show in the appendix, it remains significant at conventional levels in robustness tests.

\section{Insert Table 7 about here}

As such, whenever we find robust evidence of significant effects of introducing ESCRs on subsequent social development, these effects are in fact in the opposite direction of the stated intention. If these adverse effects were evidence of government action, we would expect to be able to identify significant economic side effects of those actions.

\subsection{Side effects - government spending and inflation}

Finally, we therefore explore two potential economic side effects of introducing ESCRs: government expenditure and inflation. If governments were serious about introducing rights to health services, education and social security, one would expect that the production of public goods would increase significantly. Public goods provision would be visible in government final expenditures (that do not 
include transfer payments), and both public goods expansion as well as pure redistribution and fiscal expansion would be expected to cause short to medium-run inflationary effects. We therefore regress the introduction of ESCRs on government expenditures and inflation (relative to the US) in Table 8a.

\section{Insert Table 8 a about here}

With the control variables, we find here a negative short-run effect of GDP per capita, entirely as one should expect, as well as short-run effects of introducing democracy, increasing populations, and opposite short and long-run effects of openness to trade. The estimates identified from the annual variation suggest that the introduction of ESCRs is associated with a long-run increase in government final expenditures. However, the estimates in columns 3-4 suggest that the overall effects are only driven by the introduction of non-justiciable rights, as there are no significant effects for justiciable rights. When instead identifying effects based on the variation across overlapping five-year periods, we find contrary evidence. The five-year estimates in Table 8b suggest that government expenditures may decrease in the medium to long run after the introduction of justiciable ESCRs. While we can only speculate as to the causes of this effect, it seems consistent with a situation in which governments legislate in an effort to provide public access to privately produced services, while rolling back access to the same or other publicly provided services.

\section{Insert Table $8 b$ about here}

Finally, employing inflation in Table $9 \mathrm{a}$ as the dependent variable suggests that the introduction of ESCRs has the expected short-run inflationary effects while the control variables produce relatively similar results as with government expenditures. These effects are stronger and more significant in developing countries and more clearly visible when we adopt a five-year time horizon in Table 9b. Here, the introduction of one ESCR on average increases inflation by .4 points and .7 points if the right is made justiciable. With an inflation rate of .35 points above the US inflation, i.e. an inflation rate of approximately 3 percent in the average country in the sample, this is a sizable effect. 


\subsection{Robustness tests}

Even though we estimate all effects in large, long-term panels, the risk remains that outlier observations or other complications prevent us from correctly identifying effects and non-effects. As such, we need to test the robustness of our main findings. We perform three such types of tests.

First, we perform a full set of country jackknife tests in which we, for each specification reported above, exclude all observations from one of the 160 countries. This way, we effectively control for the possibility that findings are biased due to one or a few countries with trends that differ substantially from the general pattern. Second, one might expect that constitutional changes take some time to take effect. While this ought to be addressed in our five-year panel estimates, we nevertheless tested whether there were differential effects beyond a five-year horizon by adding a dummy capturing whether a right had been implemented during the last five years.

A final possibility is that ESCRs might reinforce each other, i.e. that there are bundling effects. We have addressed this issue by re-running our specifications including additional dummy variables capturing whether the central right - e.g. the right to health in health specifications - is bundled with another right.

However, while we find somewhat fragile evidence that some side effects only become significant when bundled, we find no evidence that the introduction of any ESCR is effective when bundled with any other right. In other words, the main finding that there are no identifiable, direct long-run consequences of introducing the right to health, education or social security is unaffected by controlling for various types of bundling of rights. 
In total, our main findings prove stable to a rather comprehensive set of robustness tests. The few, apparently significant, effects we find for the association between health rights and immunization turn out to be driven by single countries, and therefore do not generalize.

\subsection{Summary of findings}

We summarize our main findings in Figure 2, in which shaded columns illustrate short to medium-run effects, i.e. consequences within a five-year periods, and full columns illustrate long-run effects. Overall, our results suggest that the introduction of ESCRs do not have any discernible positive long-run consequences on health, education or poverty and income inequality. Estimates of the effects of rights to health on health outcomes are small and very far from significant, and the positive association with immunization rates is driven by very few outlier countries. Estimates of the effects of rights to social security on income inequality are positive but insignificant; and the long-run estimate of effects of rights to education on average educational attainment is negative, but far from significant. ${ }^{11}$ However, as illustrated in the figure, we note that the introduction of education rights is associated with a drop in educational attainment in the medium-run.

In addition, the introduction of any right is associated with a medium-run increase in inflation, as measured by the development of the PW'T purchasing power adjustment indicator. As such, the evidence does not suggest that the absence of effects is due to inaction on the side of governments. If so, it would be unlikely that we would observe any economic consequences. Since we do, we note that

${ }^{11}$ While we report the results of a full jackknife exercise, we have also performed a set of additional robustness tests. These tests show that the main findings are robust to choosing other cut-offs at which we define developing countries. The noneffects of introducing ESCRs are also unaffected by controlling for how long a set of rights have been part of the constitution. As such, it is not the case that we fail to identify positive effects due to longer lags or delayed effective implementation. 
whatever governments do when introducing ESCRs is at best ineffective. With this finding, we proceed to the conclusions.

\section{Discussion and conclusions}

A growing number of countries have introduced ESCRs in their constitutions since the 1960s. This type of rights is heavily advocated by the United Nations and various international NGOs, and now form part of the development strategy of multiple developing countries and donors alike. These organizations argue that giving people a legally enforceable right to, e.g., health services, education or social security will improve overall levels of health and education of the population and lead to less poverty and economic inequality. However, little is known about the actual consequences of introducing such rights or making them directly justiciable.

In this paper, we therefore analyzed the introduction of the right to health, education and social security on a set of subsequent outcomes, as well as two unintended but a priori likely side effects. We first noted that the theoretical expectation is ambiguous from both a judicial and a political-economic point of view. From a legal point of view the increasing number of national constitutions including ESCRs is still some way from representing an emerging state practice. Numerous states, including liberal democracies, still do not include most ESCRs in their constitutions. Moreover, several of the countries that do include ESCRs in their constitutions have excluded or limited the justiciability of such rights. At the international level few states have ratified the Optional Protocol to the ICESCR, which allows for individual complaints alleging violations of ESCRs. Moreover, the most highly developed regional human rights protection systems in Europe (ECHR and EU Charter) and the Americas (ACHR) still have not been expanded to formally include ESCRs or treat CPRs and ESCRs differently. The continued gulf in the protection of ESCRs vis-à-vis CPRs reflects continued concerns about the appropriateness of making ESCRs justiciable due to the consequences for, inter alia, legal clarity and the separation of powers. While the entrenchment of ESCRs in national constitutions and international 
law has made important and impressive gain it is thus still some way from reflecting the nominal international consensus on the "indivisibility" of all human rights. From a political-economic point of view, enforcement is likely to be associated with unintended political and economic side effects that can more than offset the intended effects.

Our results from applying an error-correction estimator to a panel of up to 160 countries observed in the period between 1960 and 2010 yielded little support for the proclaimed positive effects of ESCRs. Contrary to popular international claims, we find negative medium-run effects of introducing the right to education, and adverse effects of introducing rights to social security on child mortality, which is a known correlate of deep poverty. We also find stable evidence of inflationary effects of introducing ESCRs that are likely to yield Dutch Disease-like effects on developing countries' international competitiveness. Conversely, we see no positive effects of introducing these rights in the long run.

The introduction of ESCRs since 1960 therefore does not seem to have had any of the intended consequences upon which much recent international policy and the recommendations of the United Nations are based. Logically, if countries have actually tried to implement and enforce these rights, as would be suggested by the economic side effects that we identify, ESCRs often cause offsetting, unintended consequences. In short, our conclusion is therefore that the historical experience since the 1960s shows that the introduction of ESCRs in national constitutions is, at best, inconsequential.

\section{References}

Amos, Jennifer. 2011. The Soviet Union and the Universal Declaration of Human Rights, 1948-1958, in Stefan-Ludwig Hoffman, ed., Human Rights in the Twentieth Century, Cambridge University Press, Cambridge, pp. 147, 150-155.

Barro, Robert J. and Jong-Wa Lee. In press. A New Data Set of Educational Attainment in the World, 1950-2010. Forthcoming in Journal of Development Economics. 
Bergh, Andreas and Therese Nilsson. 2010. Good for Living? On the Relation between Globalization and Life Expectancy. World Development, 38, 191-1203.

Bjørnskov, Christian. 2010. Do Elites Benefit from Democracy and Foreign Aid in Developing Countries? Journal of Development Economics, 92, 115-124.

Bjørnskov, Christian. 2011. Constitutional Property Rights Protection and Economic Growth: Evidence from the Post-Communist Transition. Working paper, Aarhus University.

Blume, Lorenz and Stefan Voigt. 2007. The Economic Effects of Human Rights. Kyklos, 60, 509-538.

De Boef, Suzanna and Luke Keele. 2008. Taking Time Seriously. American Journal of Political Science, 52, 184-200.

Chauffour, Jean-Pierre. 2011. What Matters for Development - Freedom or Entitlements? In James Gwartney and Robert Lawson (eds.), Economic Freedom of the World: 2011 Annual Report. Vancouver: the Fraser Institute, 167-178.

Chong, Alberto. 2004. Inequality, Democracy, and Persistence: Is there a Political Kuznets Curve? Economics and Politics, 16, 189-212.

Cingranelli, David L. and David L. Richards. 1999. Measuring the Level, Pattern, and Sequence of Government Respect for Physical Integrity Rights. International Studies Quarterly, 43, 407-418.

Dennis, Michael J. and David P. Stewart. 2004. Justiciability of Economic, Social and Cultural Rights: Should there be an International Complaints Mechanism to Adjudicate the Rights to Food, Water, Housing, and Health? American Journal of International Law, 98, 462-515.

Dreher, Axel, Martin Gassebner and Lars-H. R. Siemers. 2012. Globalization, Economic Freedom and Human Rights. Journal of Conflict Resolution, 56, 509-539.

Feld, Lars and Stefan Voigt. 2003. Economic Growth and Judicial Independence: Cross-Country Evidence Using a New Set of Indicators. European Journal of Political Economy, 19, 497-527.

Friedman, Milton. 1962. Capitalism and Freedom. University of Chicago Press, Chicago. 
Getgen, Jocelyn E. and Benjamin Mason Meier. 2009. Ratification of Human Rights Treaties: The Beginning not the End. Lancet, 374, 447-448.

Heston, Alan, Robert Summers and Betina Aten. 2010. Penn World Tables Version 7.0. Philadelphia, Center for International Comparisons of Production, Income and Prices, University of Pennsylvania.

Howard-Hessman, Rhonda E. and Welch Jnr., Claude E., 2006. Economic Rights in Canada and the United States. University of Pennsylvania Press, Philadelphia.

Jackman, Martha, 2010. Charter Remedies for Socio-economic Rights Violations: Sleeping Under a Box? in Robert J Sharpe \& Kent Roach, eds, Taking Remedies Seriously. Montreal, Canadian Institute for the Administration of Justice, 279-301.

Jayawickrama, Nihal. 2002. The Judicial Application of Human Rights Law: National, Regional and International Jurisprudence. Cambridge University Press, Cambridge.

Jung, Courtney. 2011. Coding Manual: A Description of the Methods and Decisions Used to Build a Cross-National Dataset of Economic and Social Rights in Developing Country Constitutions. Department of Political Science, University of Toronto.

Jung, Courtney and Evan Rosevear. 2011. Economic and Social Rights in Developing Countries Constitutions. Preliminary Report on the TSIER Dataset. Draft report, University of Toronto.

Langford, Malcolm. 2008. Social Rights Jurisprudence. Emerging Trends in International and Comparative Law. Cambridge University Press, Cambridge.

Langford, Malcolm. 2009. Domestic Adjudication and Economic, Social and Cultural Rights: A SocioLegal Review. Sur International Journal of Human Rights, Vol. 6, No. 11, 98-133.

Lawson, Robert and J.R. Clark. 2010. Examining the Hayek-Friedman Hypothesis on Economic and Political Freedom. Journal of Economic Behavior and Organization, 74, 230-239.

Libman, Alexander. 2010.Constitutions, Regulations, and Taxes: Contradictions of Different Aspects of Decentralization. Journal of Comparative Economics, 38, 395-418. 
Maddala, G.S. and Shaowen Wu. 1999. A Comparative Study of Unit Root Tests with Panel Data and New Simple Test. Oxford Bulletin of Economics and Statistics, 61, 631-652.

Marshall, Monty G. and Keith Jaggers. 2010. Polity IV Project: Political Regime Characteristics and Transitions, 1800-2008: Dataset and Codebook. Online database, available at http://www.cidcm.umd.edu/polity (Accessed March 2012).

Mbazira, Christopher, 2009. Litigating Socio-economic Rights in South Africa: A Choice Between Corrective and Distributive Justice. Pretoria University Law Press, Pretoria South Africa, pp. 63-64, 135.

Mueller, Dennis. 2003. Public Choice III. Cambridge University Press, Cambridge, UK.

Nikkel, James W. 2008 Rethinking Indivisibility: Towards a Theory of Supporting Relations between Human Rights. Human Rights Quarterly, 30, 984-1001.

North, Douglass C. 1990. Institutions, Institutional Change, and Economic Performance. Cambridge University Press, Cambridge UK.

Palmer, Alexis, Jocelyn Tomkinson, Charlene Phung, Nathan Ford, Michel Joffres, Kimberly A. Fernandes, Leilei Zeng, Viviane Lima, Julio S.G. Montaner, Gordon H. Guyatt, and Edward J. Mills. 2009. Does Ratification of Human-Rights Treaties have Effects on Population Health? Lancet, 373, 1987-1992.

Rajan, Raghuram G. and Arvind Subramanian. 2011. Aid, Dutch Disease, and manufacturing growth. Journal of Development Economics, 94, 106-118.

Remmer, Karen. 2004. Does Foreign Aid Promote the Expansion of Government? American Journal of Political Science, 48, 77-92.

Richards, David L., Ronald Gelleny and David Sacko. 2001. Money with a Mean Streak? Foreign Economic Penetration and Government Respect for Human Rights in Developing Countries. International Studies Quarterly, 45, 219-239.

Rode, Martin and James D. Gwartney. 2012. Does Democratization Facilitate Economic Liberalization? European Journal of Political Economy, 28, 607-619. 
Rodrik, Dani, Arvind Subramanian and Francisco Trebbi. 2004. Institutions Rule: The Primacy of Institutions over Geography and Integration in Economic Development. Journal of Economic Growth, 9, $131-165$.

Roosevelt, Eleanor. 1951. Statement on Draft Covenant on Human Rights. Department of State Bulletin, December 31, 1951, pp. 1059, 1064-106; as cited in Hope Lewis, 'New' Human Rights: U.S. Ambivalence Toward the International Economic and Social Rights Framework, in Cynthia Soohoo, Catherine Albisa, and Martha F. Daives, eds.,Bringing Human Rights Home, Vol. 1, 2008, Praeger Publishers, USA, 103, 140 note 71.

Solt, Frederic. 2009. Standardizing the World Income Inequality Database, Social Science Quarterly 90(2): 231-242. SWIID Version 3.1, December 2011.

Tornell, Aron and Philip R. Lane. 1999. The Voracity Effect. American Economic Review, 89, 22-46.

Voigt, Stefan. 2012. How to Measure the Rule of Law. Kyklos, 65, 262-284.

Vreeland, James Raymond. 2008. Political Institutions and Human Rights: Why Dictatorships enter into the United Nations Convention against Torture. International Organization, 62, 65-101.

Whelan, Daniel J. 2010. Indivisibility of Human Rights: A History. University of Pennsylvania Press, Philadelphia.

WHO. 2012. World Health Organization. Website and online database, available at http://www.who.int/en/.

WIPO. 2012. World Intellectual Property Organization. Website, available at http://www.wipo.int/wipolex/en/national.jsp\#13 (accessed May-June 2012).

World Bank. 2012. World Development Indicators. Online database, the World Bank, Washington DC. 
Table 1a. Countries enforcing ESCRs, A-L

\begin{tabular}{|c|c|c|c|c|c|c|c|}
\hline Country & Type & Year & Judiciable & Country & Type & Year & Judiciable \\
\hline Afghanistan & $\mathrm{E}, \mathrm{H}$ & 2004 & No & El Salvador & $\mathrm{E}, \mathrm{H}, \mathrm{S}$ & 1983 & All \\
\hline Albania & $\mathrm{E}, \mathrm{H}, \mathrm{S}$ & 1946 & Since 1998 & Eq. Guinea & E & 1995 & No \\
\hline Algeria & $\mathrm{E}, \mathrm{H}$ & 1976 & No & Estonia & $\mathrm{E}, \mathrm{H}, \mathrm{S}$ & Soviet & Since 1992 \\
\hline Angola & $\mathrm{H}, \mathrm{S}$ & 1992 & $\mathrm{H}$ & Ethiopia & $\mathrm{E}, \mathrm{H}, \mathrm{S}$ & 1987 & $\mathrm{H}, \mathrm{S}$ \\
\hline Argentina & E, S & 1853 & $\mathrm{E}, \mathrm{S}$ & Fiji & $\mathrm{E}$ & 1997 & No \\
\hline Armenia & $\mathrm{E}, \mathrm{H}, \mathrm{S}$ & Soviet & Since 1995 & Finland & $\mathrm{E}, \mathrm{H}, \mathrm{S}$ & 1919 & No \\
\hline Azerbaijan & $\mathrm{E}, \mathrm{H}, \mathrm{S}$ & Soviet & Since 1995 & Gabon & $\mathrm{H}, \mathrm{S}$ & 1991 & No \\
\hline Bahrain & $\mathrm{E}, \mathrm{H}, \mathrm{S}$ & 1973 & No & Gambia & $\mathrm{E}$ & 1997 & $\mathrm{E}$ \\
\hline Bangladesh & $\mathrm{H}, \mathrm{S}$ & 1972 & $\mathrm{No}$ & Georgia & E, $\mathrm{H}$ & 1995 & $\mathrm{E}, \mathrm{H}$ \\
\hline Belarus & $\mathrm{E}, \mathrm{H}, \mathrm{S}$ & Soviet & Since 1994 & Ghana & E, S & 1992 & $\mathrm{E}$ \\
\hline Belgium & $\mathrm{E}, \mathrm{H}, \mathrm{S}$ & 1994 & No & Greece & $\mathrm{E}, \mathrm{H}$ & 1975 & No \\
\hline Benin & E, S & 1990 & $\mathrm{E}$ & Guatemala & $\mathrm{E}, \mathrm{H}, \mathrm{S}$ & 1985 & All \\
\hline Bhutan & $\mathrm{E}, \mathrm{H}$ & 2008 & No & Guinea-Bissau & $\mathrm{E}, \mathrm{H}$ & 1984 & $\mathrm{E}, \mathrm{H}$ \\
\hline Bolivia & E, $\mathrm{H}$ & 1967 & E, $\mathrm{H}$ & Guyana & $\mathrm{E}, \mathrm{H}, \mathrm{S}$ & 1990 & No \\
\hline Bosnia & $\mathrm{E}$ & 1995 & No & Haiti & $\mathrm{E}, \mathrm{H}, \mathrm{S}$ & 1987 & No \\
\hline Brazil & $\mathrm{E}, \mathrm{H}, \mathrm{S}$ & 1998 & All & Honduras & $\mathrm{E}, \mathrm{S}$ & 1982 & $\mathrm{E}, \mathrm{S}$ \\
\hline Bulgaria & $\mathrm{E}, \mathrm{H}, \mathrm{S}$ & Soviet & $\mathrm{No}$ & Hungary & $\mathrm{E}, \mathrm{H}, \mathrm{S}$ & 1949 & $\mathrm{E}, \mathrm{H}, \mathrm{S}$ \\
\hline Burkina Faso & $\mathrm{E}, \mathrm{H}, \mathrm{S}$ & 1997 & No & Iceland & E, S & 1944 & No \\
\hline Burundi & $\mathrm{E}, \mathrm{H}$ & 1992 & E, $\mathrm{H}$ & India & $\mathrm{E}$ & 2002 & $\mathrm{E}$ \\
\hline Cambodia & $\mathrm{E}, \mathrm{H}, \mathrm{S}$ & 1993 & No & Indonesia & $\mathrm{E}, \mathrm{S}$ & 1945 & No \\
\hline CAF & $\mathrm{E}$ & 1994 & No & Iran & $\mathrm{E}, \mathrm{H}, \mathrm{S}$ & 1979 & $\mathrm{E}, \mathrm{S}$ \\
\hline Chad & $\mathrm{E}$ & 1996 & $\mathrm{E}$ & Iraq & $\mathrm{E}, \mathrm{H}, \mathrm{S}$ & 2005 & No \\
\hline Chile & E, H, S & 1990 & No & Ireland & $\mathrm{E}$ & 1937 & No \\
\hline China & $\mathrm{E}, \mathrm{S}$ & 1982 & No & Italy & $\mathrm{E}, \mathrm{H}, \mathrm{S}$ & 1947 & No \\
\hline Colombia & $\mathrm{E}, \mathrm{H}, \mathrm{S}$ & 1991 & No & Japan & $\mathrm{E}, \mathrm{S}$ & 1947 & $\mathrm{E}, \mathrm{S}$ \\
\hline Congo, Rep. & $\mathrm{E}, \mathrm{H}$ & 1992 & No & Jordan & $\mathrm{E}, \mathrm{S}$ & 1952 & No \\
\hline Congo, DR & $\mathrm{E}, \mathrm{H}, \mathrm{S}$ & 2006 & All & Kazakhstan & $\mathrm{E}, \mathrm{H}, \mathrm{S}$ & Soviet & All \\
\hline Costa Rica & $\mathrm{E}, \mathrm{S}$ & 1949 & $\mathrm{E}, \mathrm{S}$ & Kenya & $\mathrm{E}, \mathrm{H}, \mathrm{S}$ & 2010 & No \\
\hline Côte d'Ivoire & S & 2000 & No & Kuwait & $\mathrm{E}, \mathrm{H}, \mathrm{S}$ & 1962 & No \\
\hline Croatia & $\mathrm{E}, \mathrm{H}, \mathrm{S}$ & 1990 & No & Kyrgyzstan & $\mathrm{E}, \mathrm{H}, \mathrm{S}$ & Soviet & No \\
\hline Cuba & $\mathrm{E}, \mathrm{H}, \mathrm{S}$ & $1940^{a}$ & No & Laos & $\mathrm{E}, \mathrm{H}$ & 1991 & No \\
\hline Cyprus & $\mathrm{E}, \mathrm{S}$ & 1960 & No & Lesotho & $\mathrm{E}$ & 1993 & No \\
\hline Czech Rep. & $\mathrm{E}$ & 1992 & No & Latvia & $\mathrm{E}, \mathrm{H}, \mathrm{S}$ & 1922 & All \\
\hline Denmark & $\mathrm{E}, \mathrm{S}$ & 1849 & No & Liberia & $\mathrm{E}$ & 1986 & No \\
\hline Dominican Rep & $\mathrm{E}, \mathrm{H}, \mathrm{S}$ & 1994 & $\mathrm{No}$ & Lebanon & $\mathrm{E}, \mathrm{H}$ & 1969 & $\mathrm{No}$ \\
\hline Ecuador & $\mathrm{E}, \mathrm{H}, \mathrm{S}$ & 1996 & All & Lithuania & $\mathrm{E}, \mathrm{H}, \mathrm{S}$ & Soviet & Since 1992 \\
\hline Egypt & E, H, S & 1971 & No & Luxembourg & E & 1868 & No \\
\hline
\end{tabular}

Note: all countries in the former Soviet Union had full rights that were non-justiciable; Cuba introduced H, S in 1976; the Czech Republic had H, S before 1992; Egypt took out the rights in 2010; Greece introduced H in 1991; Laos introduced H in 2003. 
Table 1b. Countries enforcing ESCRs, M-Z

\begin{tabular}{|c|c|c|c|c|c|c|c|}
\hline Country & Type & Year & Judiciable & Country & Type & Year & Judiciable \\
\hline Madagascar & $\mathrm{E}, \mathrm{H}$ & 1992 & No & Serbia & $\mathrm{E}, \mathrm{H}, \mathrm{S}$ & 1990 & All \\
\hline Macedonia & $\mathrm{E}, \mathrm{H}, \mathrm{S}$ & 1991 & No & Seychelles & $\mathrm{E}, \mathrm{H}, \mathrm{S}$ & 1993 & All \\
\hline Malawi & E, H & 1994 & $\mathrm{E}, \mathrm{H}$ & Sierra Leone & $\mathrm{E}, \mathrm{H}, \mathrm{S}$ & 1991 & No \\
\hline Maldives & $\mathrm{E}, \mathrm{H}$ & 2008 & No & Slovakia & E, H, S & 1992 & $\mathrm{No}$ \\
\hline Mali & $\mathrm{E}, \mathrm{H}, \mathrm{S}$ & 1992 & No & Slovenia & $\mathrm{E}, \mathrm{H}, \mathrm{S}$ & 1991 & All \\
\hline Malta & $\mathrm{E}, \mathrm{S}$ & 1964 & No & Somalia & E, H, S & 1990 & No \\
\hline Marshall Islands & $\mathrm{E}, \mathrm{H}$ & 1979 & No & Spain & $\mathrm{E}, \mathrm{H}, \mathrm{S}$ & 1978 & No \\
\hline Mexico & $\mathrm{E}, \mathrm{H}, \mathrm{S}$ & 1917 & All & Sri Lanka & $\mathrm{E}, \mathrm{S}$ & 1978 & No \\
\hline Micronesia & $\mathrm{E}, \mathrm{H}$ & 1975 & $\mathrm{No}$ & Sudan & E, $\mathrm{H}$ & 2005 & $\mathrm{E}, \mathrm{H}$ \\
\hline Moldova & $\mathrm{E}, \mathrm{H}, \mathrm{S}$ & Soviet & Since 1994 & Suriname & $\mathrm{E}, \mathrm{H}$ & 1987 & No \\
\hline Mongolia & $\mathrm{E}, \mathrm{H}, \mathrm{S}$ & 1992 & All & South Africa & E, H, S & 1997 & All \\
\hline Mozambique & $\mathrm{E}, \mathrm{H}$ & 1990 & Since 2004 & South Korea & $\mathrm{E}, \mathrm{H}$ & 1948 & No \\
\hline Nepal & $\mathrm{E}, \mathrm{H}, \mathrm{S}$ & 1990 & Since 2007 & Swaziland & $\mathrm{E}, \mathrm{S}$ & 2005 & No \\
\hline Netherlands & $\mathrm{E}, \mathrm{H}, \mathrm{S}$ & 1983 & No & Syria & $\mathrm{E}, \mathrm{H}, \mathrm{S}$ & 1973 & $\mathrm{No}$ \\
\hline Nicaragua & $\mathrm{E}, \mathrm{H}, \mathrm{S}$ & 1987 & All & Tajikistan & E, H, S & Soviet & Since 1994 \\
\hline Nigeria & $\mathrm{E}, \mathrm{H}, \mathrm{S}$ & 1976 & No & Tanzania & $\mathrm{E}, \mathrm{S}$ & 1977 & No \\
\hline Oman & $\mathrm{E}, \mathrm{H}, \mathrm{S}$ & 1996 & $\mathrm{No}$ & Thailand & E, H, S & 1932 & $\mathrm{No}$ \\
\hline Pakistan & $\mathrm{E}, \mathrm{H}, \mathrm{S}$ & 1973 & No & Togo & $\mathrm{E}, \mathrm{H}$ & 1992 & No \\
\hline Panama & $\mathrm{E}, \mathrm{H}, \mathrm{S}$ & 1972 & All & Turkey & E, H, S & 1961 & Since 1982 \\
\hline Paraguay & $\mathrm{E}, \mathrm{H}, \mathrm{S}$ & 1967 & Since 1992 & Turkmenistan & $\mathrm{E}, \mathrm{H}, \mathrm{S}$ & Soviet & Since 1992 \\
\hline Peru & $\mathrm{E}, \mathrm{H}, \mathrm{S}$ & 1979 & Since 1993 & Uganda & $\mathrm{E}, \mathrm{S}$ & 1995 & $\mathrm{E}, \mathrm{S}$ \\
\hline Poland & $\mathrm{E}, \mathrm{H}, \mathrm{S}$ & 1952 & Since 1997 & Ukraine & $\mathrm{E}, \mathrm{H}, \mathrm{S}$ & Soviet & Since 1996 \\
\hline Portugal & $\mathrm{E}, \mathrm{H}, \mathrm{S}$ & 1976 & No & UAE & $\mathrm{E}, \mathrm{H}$ & 1971 & No \\
\hline Qatar & $\mathrm{E}$ & 2003 & No & Uruguay & E, H, S & 1967 & Since 2004 \\
\hline Romania & $\mathrm{E}, \mathrm{H}, \mathrm{S}$ & 1948 & Since 1991 & Uzbekistan & E, H, S & Soviet & Since 1991 \\
\hline Russia & $\mathrm{E}, \mathrm{H}, \mathrm{S}$ & Soviet & Since 1993 & Venezuela & $\mathrm{E}, \mathrm{H}, \mathrm{S}$ & 1947 & Since 1999 \\
\hline Rwanda & $\mathrm{E}, \mathrm{H}$ & 1991 & No & Vietnam & E, H, S & 1946 & $\mathrm{No}$ \\
\hline São Tomé & $\mathrm{E}, \mathrm{H}, \mathrm{S}$ & 1975 & All & Yemen & $\mathrm{E}, \mathrm{H}, \mathrm{S}$ & 1990 & No \\
\hline Saudi Arabia & $\mathrm{E}, \mathrm{H}, \mathrm{S}$ & 1992 & No & Zambia & $\mathrm{E}, \mathrm{H}, \mathrm{S}$ & 1991 & No \\
\hline Switzerland & $\mathrm{E}, \mathrm{S}$ & 1874 & $\mathrm{No}$ & Zimbabwe & $\mathrm{H}$ & 1979 & $\mathrm{No}$ \\
\hline Senegal & $\mathrm{E}, \mathrm{H}$ & 2001 & No & & & & \\
\hline
\end{tabular}


Table 2. Descriptive statistics

\begin{tabular}{|c|c|c|c|c|c|}
\hline Variable & Mean & Std. deviation & Minimum & Maximum & \#Obs. \\
\hline Health rights & .355 & .479 & 0 & 1 & 9028 \\
\hline Health rights (just) & .109 & .311 & 0 & 1 & 9028 \\
\hline Education rights & .490 & .499 & 0 & 1 & 9028 \\
\hline Education rights (just) & .149 & .356 & 0 & 1 & 9028 \\
\hline Security rights & .393 & .488 & 0 & 1 & 9028 \\
\hline Security rights (just) & .128 & .335 & 0 & 1 & 9028 \\
\hline Life expectancy & 62.049 & 11.611 & 26.819 & 82.931 & 8888 \\
\hline Dependency ratio & 9.822 & 5.715 & .518 & 35.743 & 9045 \\
\hline Democracy & .013 & 7.574 & -10 & 10 & 7839 \\
\hline $\begin{array}{l}\text { Primary school enrollment } \\
\text { (gross) }\end{array}$ & 95.565 & 24.791 & 2.659 & 232.841 & 5738 \\
\hline $\begin{array}{l}\text { Secondary school } \\
\text { enrollment (gross) }\end{array}$ & 59.628 & 34.145 & 0 & 166.172 & 5031 \\
\hline Inequality, net & 37.785 & 10.581 & 15.048 & 71.327 & 4369 \\
\hline Inequality, market & 44.439 & 9.254 & 17.590 & 77.965 & 4301 \\
\hline Log GDP per capita & 8.262 & 1.304 & 4.764 & 11.979 & 7679 \\
\hline GDP growth & 1.951 & 4.005 & -42.570 & 40.978 & 7507 \\
\hline Log population size & 8.412 & 1.954 & 3.707 & 14.096 & 9000 \\
\hline Government expenditures & 12.193 & 8.959 & .268 & 68.089 & 7689 \\
\hline Openness & 76.002 & 48.756 & 1.959 & 453.437 & 7689 \\
\hline Communist & .124 & .329 & 0 & 1 & 9028 \\
\hline Postcommunist & .054 & .225 & 0 & 1 & 9028 \\
\hline
\end{tabular}


Table 3a. Main results, Life expectancy, annual observations

\begin{tabular}{|c|c|c|c|c|}
\hline & $\begin{array}{c}\text { All observations } \\
1\end{array}$ & $\begin{array}{c}\text { Below USD } 14,000 \\
2\end{array}$ & $\begin{array}{c}\text { All observations } \\
3\end{array}$ & $\begin{array}{c}\text { Below USD } 14,000 \\
4\end{array}$ \\
\hline Lagged life & $-.074 * * *$ & $-.076^{* * *}$ & $-.073^{* * *}$ & $-.076 * * *$ \\
\hline expectancy & $(.005)$ & $(.005)$ & $(.005)$ & $(.005)$ \\
\hline \multirow[t]{2}{*}{$\Delta$ age dependency } & -.009 & -.063 & -.012 & -.065 \\
\hline & $(.059)$ & $(.069)$ & $(.059)$ & $(.069)$ \\
\hline \multirow[t]{2}{*}{ Lag age dependency } & -.018 & -.004 & -.017 & -.005 \\
\hline & $(.012)$ & $(.020)$ & $(.012)$ & $(.020)$ \\
\hline \multirow[t]{2}{*}{$\Delta \log$ GDP per capita } & -.049 & -.078 & -.046 & -.078 \\
\hline & $(.041)$ & $(.041)$ & $(.041)$ & $(.041)$ \\
\hline Lag log GDP per & $-.139 * * *$ & $-.189 * * *$ & $-.132 * * *$ & $-.189 * * *$ \\
\hline capita & $(.044)$ & $(.049)$ & $(.044)$ & $(.049)$ \\
\hline \multirow[t]{2}{*}{$\Delta$ democracy } & -.000 & -.001 & .000 & -.000 \\
\hline & $(.002)$ & $(.001)$ & $(.002)$ & $(.001)$ \\
\hline \multirow[t]{2}{*}{ Lag democracy } & .001 & .000 & .002 & .001 \\
\hline & $(.002)$ & $(.002)$ & $(.002)$ & $(.002)$ \\
\hline \multirow[t]{2}{*}{$\Delta$ communist } & $.166^{* * *}$ & $.173^{* * *}$ & $.168^{* * *}$ & $.174 * * *$ \\
\hline & $(.059)$ & $(.055)$ & $(.059)$ & $(.055)$ \\
\hline \multirow[t]{2}{*}{ Lag communist } & $.203^{* *}$ & $.212^{* * *}$ & $.207 * *$ & $.214^{* * *}$ \\
\hline & $(.082)$ & $(.079)$ & $(.082)$ & $(.079)$ \\
\hline \multirow[t]{2}{*}{$\Delta$ population } & -.061 & -.205 & -.044 & -.203 \\
\hline & $(.146)$ & $(.168)$ & $(.146)$ & $(.168)$ \\
\hline \multirow[t]{2}{*}{ Lag population } & $-.439 * * *$ & $-.643 * * *$ & $-.398 * * *$ & $-.636 * * *$ \\
\hline & $(.133)$ & $(.183)$ & $(.131)$ & $(.183)$ \\
\hline \multirow[t]{2}{*}{$\Delta$ openness } & -.000 & -.000 & -.000 & -.000 \\
\hline & $(.000)$ & $(.000)$ & $(.000)$ & $(.000)$ \\
\hline \multirow[t]{2}{*}{ Lag openness } & -.000 & -.000 & -.000 & .000 \\
\hline & $(.000)$ & $(.000)$ & $(.000)$ & $(.000)$ \\
\hline \multirow[t]{2}{*}{$\Delta$ health rights } & .038 & .028 & & \\
\hline & $(.029)$ & $(.029)$ & & \\
\hline \multirow[t]{2}{*}{ Lag health rights } & .058 & .051 & & \\
\hline & $(.038)$ & $(.039)$ & & \\
\hline \multirow[t]{2}{*}{$\Delta$ health rights (just) } & & & .035 & .019 \\
\hline & & & $(.038)$ & $(.036)$ \\
\hline \multirow[t]{2}{*}{ Lag health rights (just) } & & & .067 & .043 \\
\hline & & & $(.049)$ & $(.049)$ \\
\hline Period fixed effects & Yes & Yes & Yes & Yes \\
\hline Observations & 6180 & 4849 & 6180 & 4849 \\
\hline Countries & .158 & 146 & 158 & 146 \\
\hline $\mathrm{R}$ squared within & .074 & .073 & .074 & .073 \\
\hline $\mathrm{R}$ squared between & .018 & .000 & .019 & .000 \\
\hline F statistic & 7.58 & 5.80 & 7.55 & 5.78 \\
\hline
\end{tabular}

Note: ${ }^{* * *}(* *)[*]$ denote significance at $\mathrm{p}<.01(\mathrm{p}<.05)[\mathrm{p}<.10]$. All estimates are FGLS with country fixed effects. 
Table 3b. Main results, Life expectancy, five-year periods

\begin{tabular}{|c|c|c|c|c|}
\hline & $\begin{array}{c}\text { All observations } \\
1\end{array}$ & $\begin{array}{c}\text { Below USD } 14,000 \\
2\end{array}$ & $\begin{array}{c}\text { All observations } \\
3\end{array}$ & $\begin{array}{c}\text { Below USD 14,000 } \\
4\end{array}$ \\
\hline Lagged life expectancy & $\begin{array}{c}-.083 * * \\
(.004)\end{array}$ & $\begin{array}{c}-.128^{* * *} \\
(.005)\end{array}$ & $\begin{array}{c}-.083^{* * *} \\
(.004)\end{array}$ & $\begin{array}{c}-.128^{* * *} \\
(.005)\end{array}$ \\
\hline$\Delta$ health rights & $\begin{array}{l}.056^{* *} \\
(.028)\end{array}$ & $\begin{array}{c}.033 \\
(.026)\end{array}$ & & \\
\hline Lag health rights & $\begin{array}{l}.076^{* *} \\
(.038)\end{array}$ & $\begin{array}{c}.054 \\
(.037)\end{array}$ & & \\
\hline$\Delta$ health rights (just) & & & $\begin{array}{c}.052 \\
(.039)\end{array}$ & $\begin{array}{c}.020 \\
(.035)\end{array}$ \\
\hline Lag health rights (just) & & & $\begin{array}{c}.034 \\
(.049)\end{array}$ & $\begin{array}{l}-.039 \\
(.048)\end{array}$ \\
\hline Period fixed effects & Yes & Yes & Yes & Yes \\
\hline Observations & 5530 & 4273 & 5530 & 4273 \\
\hline Countries & 156 & 136 & 156 & 136 \\
\hline $\mathrm{R}$ squared within & .082 & .159 & .104 & .159 \\
\hline $\mathrm{R}$ squared between & .010 & .004 & .010 & .004 \\
\hline F statistic & 8.06 & 13.03 & 10.44 & 13.08 \\
\hline
\end{tabular}


Table 4a. Main results, Immunization, annual observations

\begin{tabular}{|c|c|c|c|c|}
\hline & $\begin{array}{c}\text { All observations } \\
1\end{array}$ & $\begin{array}{l}\text { Below USD } 14,000 \\
2\end{array}$ & $\begin{array}{c}\text { All observations } \\
3\end{array}$ & $\begin{array}{c}\text { Below USD } 14,000 \\
4\end{array}$ \\
\hline Lagged Immunization & $\begin{array}{c}.185^{* * * *} \\
(.016)\end{array}$ & $\begin{array}{c}-.199 * * * \\
(.019)\end{array}$ & $\begin{array}{c}-183^{* * *} \\
(.016)\end{array}$ & $\begin{array}{c}-198^{* * *} \\
(.019)\end{array}$ \\
\hline$\Delta$ age dependency & $\begin{array}{c}.018 \\
(.869)\end{array}$ & $\begin{array}{l}-.763 \\
(1.362)\end{array}$ & $\begin{array}{l}-.081 \\
(.867)\end{array}$ & $\begin{array}{l}-1.007 \\
(1.356)\end{array}$ \\
\hline Lag age dependency & $\begin{array}{l}-.003 \\
(.125)\end{array}$ & $\begin{array}{l}.106 \\
(.246)\end{array}$ & $\begin{array}{l}.003 \\
(.125)\end{array}$ & $\begin{array}{l}.097 \\
(.247)\end{array}$ \\
\hline$\Delta \log$ GDP per capita & $\begin{array}{l}2.601^{*} \\
(1.55)\end{array}$ & $\begin{array}{c}2.351 \\
(1.787)\end{array}$ & $\begin{array}{l}2.662^{*} \\
(1.553)\end{array}$ & $\begin{array}{c}2.452 \\
(1.790)\end{array}$ \\
\hline $\begin{array}{l}\text { Lag log GDP per } \\
\text { capita }\end{array}$ & $\begin{array}{c}-2.186^{* * *} \\
(.552)\end{array}$ & $\begin{array}{c}-2.495^{* * *} \\
(.700)\end{array}$ & $\begin{array}{c}-2.218^{* * *} \\
(.554)\end{array}$ & $\begin{array}{c}-2.494^{* * *} \\
(.705)\end{array}$ \\
\hline$\Delta$ democracy & $\begin{array}{l}-.076 \\
(.056)\end{array}$ & $\begin{array}{l}-.058 \\
(.061)\end{array}$ & $\begin{array}{l}-.077 \\
(.056)\end{array}$ & $\begin{array}{l}-.060 \\
(.060)\end{array}$ \\
\hline Lag democracy & $\begin{array}{l}-.016 \\
(0.036)\end{array}$ & $\begin{array}{c}.012 \\
(.041)\end{array}$ & $\begin{array}{l}-.006 \\
(.036)\end{array}$ & $\begin{array}{c}.023 \\
(.041)\end{array}$ \\
\hline$\Delta$ communist & $\begin{array}{l}-.778 \\
(2.401)\end{array}$ & $\begin{array}{l}-.618 \\
(2.632)\end{array}$ & $\begin{array}{l}-.890 \\
(2.402)\end{array}$ & $\begin{array}{l}-.791 \\
(2.633)\end{array}$ \\
\hline Lag communist & $\begin{array}{c}-3.575^{* * *} \\
(1.144)\end{array}$ & $\begin{array}{c}-4.397 * * * \\
(1.320)\end{array}$ & $\begin{array}{c}-3.534 * * * \\
(1.144)\end{array}$ & $\begin{array}{c}-4.441 * * * \\
(1.326)\end{array}$ \\
\hline$\Delta$ population & $\begin{array}{l}7.266 \\
(4.699)\end{array}$ & $\begin{array}{c}20.637 * * * \\
(6.738)\end{array}$ & $\begin{array}{l}7.506 \\
(4.7)\end{array}$ & $\begin{array}{c}21.143^{* * * *} \\
(6.737)\end{array}$ \\
\hline Lag population & $\begin{array}{c}-3.141 * * \\
(1.557)\end{array}$ & $\begin{array}{l}-.326 \\
(2.324)\end{array}$ & $\begin{array}{l}-2.793^{*} \\
(1.548)\end{array}$ & $\begin{array}{c}.172 \\
(2.327)\end{array}$ \\
\hline$\Delta$ openness & $\begin{array}{l}-.008 \\
(.009)\end{array}$ & $\begin{array}{l}-.013 \\
(.010)\end{array}$ & $\begin{array}{l}-.007 \\
(.009)\end{array}$ & $\begin{array}{l}-.013 \\
(.010)\end{array}$ \\
\hline Lag openness & $\begin{array}{c}.001 \\
(.006)\end{array}$ & $\begin{array}{l}-.001 \\
(.007)\end{array}$ & $\begin{array}{l}.001 \\
(.006)\end{array}$ & $\begin{array}{l}-.001 \\
(.007)\end{array}$ \\
\hline$\Delta$ health rights & $\begin{array}{l}-.242 \\
(.974)\end{array}$ & $\begin{array}{l}-.297 \\
(1.134)\end{array}$ & & \\
\hline Lag health rights & $\begin{array}{l}.860^{*} \\
(.521)\end{array}$ & $\begin{array}{l}.929 \\
(.614)\end{array}$ & & \\
\hline$\Delta$ health rights (just) & & & $\begin{array}{c}1.400 \\
(1.209)\end{array}$ & $\begin{array}{c}1.422 \\
(1.319)\end{array}$ \\
\hline Lag health rights (just) & & & $\begin{array}{l}.295 \\
(.652)\end{array}$ & $\begin{array}{l}.429 \\
(.725)\end{array}$ \\
\hline Period fixed effects & Yes & Yes & Yes & Yes \\
\hline Observations & 3733 & 2814 & 3733 & 2814 \\
\hline Countries & 158 & 126 & 158 & 126 \\
\hline $\mathrm{R}$ squared within & .116 & .131 & .115 & .130 \\
\hline $\mathrm{R}$ squared between & .009 & .042 & .001 & .072 \\
\hline F statistic & 11.04 & 9.48 & 11.22 & 9.65 \\
\hline
\end{tabular}

Note: $* * *(* *)\left[{ }^{*}\right]$ denote significance at $\mathrm{p}<.01(\mathrm{p}<.05)[\mathrm{p}<.10]$. All estimates are FGLS with country fixed effects. 
Table 4b. Main results, Immunization, five-year periods

\begin{tabular}{|c|c|c|c|c|}
\hline & $\begin{array}{c}\text { All observations } \\
1\end{array}$ & $\begin{array}{c}\text { Below USD } 14,000 \\
2\end{array}$ & $\begin{array}{c}\text { All observations } \\
3\end{array}$ & $\begin{array}{c}\text { Below USD } 14,000 \\
4\end{array}$ \\
\hline Lagged Immunization & $\begin{array}{l}-1.005^{* * *} \\
(.015)\end{array}$ & $\begin{array}{c}-1.011 * * * \\
(.018)\end{array}$ & $\begin{array}{c}-1.006^{* * *} \\
(.015)\end{array}$ & $\begin{array}{c}-1.012^{* * *} \\
(.018)\end{array}$ \\
\hline$\Delta$ health rights & $\begin{array}{l}1.428 \\
(0.887)\end{array}$ & $\begin{array}{c}1.343 \\
(1.051)\end{array}$ & & \\
\hline Lag health rights & $\begin{array}{c}2.825 * * \\
(1.219)\end{array}$ & $\begin{array}{l}2.739 * \\
(1.462)\end{array}$ & & \\
\hline$\Delta$ health rights (just) & & & $\begin{array}{c}2.542^{* *} \\
(1.177)\end{array}$ & $\begin{array}{l}2.429 * \\
(1.314)\end{array}$ \\
\hline Lag health rights (just) & & & $\begin{array}{c}4.136^{* *} \\
(1.547)\end{array}$ & $\begin{array}{l}4.075^{*} \\
(1.728)\end{array}$ \\
\hline Period fixed effects & Yes & Yes & Yes & Yes \\
\hline Observations & 3231 & 2415 & 3231 & 2415 \\
\hline Countries & 156 & 124 & 156 & 124 \\
\hline $\mathrm{R}$ squared within & .624 & .618 & .624 & .619 \\
\hline $\mathrm{R}$ squared between & .059 & .158 & .059 & .158 \\
\hline F statistic & 135.98 & 98.73 & 136.13 & 93.79 \\
\hline
\end{tabular}

Note: $* * *(* *)[*]$ denote significance at $\mathrm{p}<.01(\mathrm{p}<.05)[\mathrm{p}<.10]$. All estimates are FGLS with country fixed effects. 
Table 5. Main results, education, five-year periods

\begin{tabular}{|c|c|c|c|c|}
\hline & $\begin{array}{c}\text { All observations } \\
\text { Average schooling } \\
1\end{array}$ & $\begin{array}{l}\text { Below USD 14,000 } \\
\text { Average schooling } \\
2\end{array}$ & $\begin{array}{c}\text { All observations } \\
\text { Average schooling } \\
3\end{array}$ & $\begin{array}{c}\text { Below USD 14,000 } \\
\text { Average schooling } \\
4\end{array}$ \\
\hline Lagged education & $\begin{array}{c}.127 * * * \\
(.019)\end{array}$ & $\begin{array}{c}-.117 * * * \\
(.019)\end{array}$ & $\begin{array}{l}-.129 * * \\
(.019)\end{array}$ & $\begin{array}{c}-.115^{* * * *} \\
(.019)\end{array}$ \\
\hline$\Delta$ age dependency & $\begin{array}{l}.026^{*} \\
(.015)\end{array}$ & $\begin{array}{c}-.048^{* *} \\
(.019)\end{array}$ & $\begin{array}{l}.026^{*} \\
(.015)\end{array}$ & $\begin{array}{c}-.046^{* *} \\
(.019)\end{array}$ \\
\hline Lag age dependency & $\begin{array}{l}-.010 \\
(.009)\end{array}$ & $\begin{array}{c}-.036^{* *} \\
(.015)\end{array}$ & $\begin{array}{l}-.010 \\
(.009)\end{array}$ & $\begin{array}{c}-.033^{* *} \\
(.015)\end{array}$ \\
\hline$\Delta \log$ GDP per capita & $\begin{array}{l}-.111 \\
(.065)\end{array}$ & $\begin{array}{l}-.045 \\
(.059)\end{array}$ & $\begin{array}{l}-.109 * \\
(.065)\end{array}$ & $\begin{array}{l}-.054 \\
(.059)\end{array}$ \\
\hline $\begin{array}{l}\text { Lag log GDP per } \\
\text { capita }\end{array}$ & $\begin{array}{l}.079 * \\
(.045)\end{array}$ & $\begin{array}{l}.088^{* *} \\
(.042)\end{array}$ & $\begin{array}{l}.079 * \\
(.045)\end{array}$ & $\begin{array}{l}.093 * * \\
(.042)\end{array}$ \\
\hline$\Delta$ democracy & $\begin{array}{l}.004 \\
(.003)\end{array}$ & $\begin{array}{l}.001 \\
(.003)\end{array}$ & $\begin{array}{l}.004 \\
(.003)\end{array}$ & $\begin{array}{l}.001 \\
(.003)\end{array}$ \\
\hline Lag democracy & $\begin{array}{l}.001 \\
(.003)\end{array}$ & $\begin{array}{l}-.001 \\
(.003)\end{array}$ & $\begin{array}{l}.002 \\
(.003)\end{array}$ & $\begin{array}{l}-.001 \\
(.003)\end{array}$ \\
\hline$\Delta$ communist & $\begin{array}{l}.210^{* *} \\
(.102)\end{array}$ & $\begin{array}{l}.195^{* *} \\
(.092)\end{array}$ & $\begin{array}{l}.209 * * \\
(.102)\end{array}$ & $\begin{array}{l}.189 * * \\
(.092)\end{array}$ \\
\hline Lag communist & $\begin{array}{c}.018 \\
(.094)\end{array}$ & $\begin{array}{l}-.086 \\
(.087)\end{array}$ & $\begin{array}{c}.030 \\
(.094)\end{array}$ & $\begin{array}{l}-.086 \\
(.087)\end{array}$ \\
\hline$\Delta$ population & $\begin{array}{r}.149 \\
(.256)\end{array}$ & $\begin{array}{l}.046 \\
(.266)\end{array}$ & $\begin{array}{l}.172 \\
(.256)\end{array}$ & $\begin{array}{l}.074 \\
(.265)\end{array}$ \\
\hline Lag population & $\begin{array}{l}.282^{* * *} \\
(.103)\end{array}$ & $\begin{array}{l}.185 \\
(.132)\end{array}$ & $\begin{array}{c}.297 * * * \\
(.104)\end{array}$ & $\begin{array}{l}.189 \\
(.133)\end{array}$ \\
\hline$\Delta$ openness & $\begin{array}{l}-.000 \\
(.001)\end{array}$ & $\begin{array}{l}-.000 \\
(.001)\end{array}$ & $\begin{array}{l}-.000 \\
(.001)\end{array}$ & $\begin{array}{c}.000 \\
(.001)\end{array}$ \\
\hline Lag openness & $\begin{array}{l}.000 \\
(.001)\end{array}$ & $\begin{array}{l}-.000 \\
(.001)\end{array}$ & $\begin{array}{l}.000 \\
(.001)\end{array}$ & $\begin{array}{l}-.000 \\
(.001)\end{array}$ \\
\hline$\Delta$ education rights & $\begin{array}{l}-.092 * * \\
(.044)\end{array}$ & $\begin{array}{c}-.127 * * * \\
(.041)\end{array}$ & & \\
\hline Lag education rights & $\begin{array}{l}.011 \\
(.039)\end{array}$ & $\begin{array}{l}-.051 \\
(.039)\end{array}$ & & \\
\hline $\begin{array}{l}\Delta \text { education rights } \\
\text { (just) } \\
\text { Lag education rights } \\
\text { (just) }\end{array}$ & & & $\begin{array}{c}-.132 * * \\
(.059) \\
-.045 \\
(.053)\end{array}$ & $\begin{array}{c}-.152 * * * \\
(.052) \\
-.019 \\
(.046)\end{array}$ \\
\hline Period fixed effects & Yes & Yes & Yes & Yes \\
\hline Observations & 995 & 757 & 995 & 757 \\
\hline Countries & 134 & 114 & 134 & 114 \\
\hline $\mathrm{R}$ squared within & .175 & .276 & .174 & .275 \\
\hline $\mathrm{R}$ squared between & .005 & .020 &. .05 & .019 \\
\hline F statistic & 7.74 & 10.27 & 7.68 & 10.23 \\
\hline
\end{tabular}

Note: $* * *(* *)[*]$ denote significance at $\mathrm{p}<.01(\mathrm{p}<.05)[\mathrm{p}<.10]$. All estimates are FGLS with country fixed effects. 
Table 6a. Main results, income inequality, annual observations

\begin{tabular}{|c|c|c|c|c|}
\hline & $\begin{array}{c}\text { All observations } \\
1 \\
\end{array}$ & $\begin{array}{c}\text { Below USD } 14,000 \\
2\end{array}$ & $\begin{array}{c}\text { All observations } \\
3 \\
\end{array}$ & $\begin{array}{c}\text { Below USD } 14,000 \\
4\end{array}$ \\
\hline Lagged inequality & $\begin{array}{c}-.188^{* * * *} \\
(.009)\end{array}$ & $\begin{array}{c}-.198^{* * *} \\
(.011)\end{array}$ & $\begin{array}{c}-.271 * * * \\
(.011)\end{array}$ & $\begin{array}{c}-.197 * * * \\
(.011)\end{array}$ \\
\hline$\Delta$ age dependency & $\begin{array}{l}-.085 \\
(.229)\end{array}$ & $\begin{array}{l}-.307 \\
(.416)\end{array}$ & $\begin{array}{l}-.243 \\
(.287)\end{array}$ & $\begin{array}{l}-.292 \\
(.416)\end{array}$ \\
\hline Lag age dependency & $\begin{array}{l}.047^{*} \\
(.027)\end{array}$ & $\begin{array}{l}.051 \\
(.066)\end{array}$ & $\begin{array}{r}.033 \\
(.034)\end{array}$ & $\begin{array}{c}.051 \\
(.065)\end{array}$ \\
\hline$\Delta \log$ GDP per capita & $\begin{array}{l}4.575^{*} \\
(2.538)\end{array}$ & $\begin{array}{c}4.448 \\
(3.293)\end{array}$ & $\begin{array}{l}4.074^{*} \\
(2.415)\end{array}$ & $\begin{array}{l}4.325 \\
(3.296)\end{array}$ \\
\hline $\begin{array}{l}\text { Lag log GDP per } \\
\text { capita }\end{array}$ & $\begin{array}{r}.482 \\
(.879)\end{array}$ & $\begin{array}{l}.335 \\
(1.121)\end{array}$ & $\begin{array}{c}1.779 * * \\
(.783)\end{array}$ & $\begin{array}{c}.436 \\
(1.122)\end{array}$ \\
\hline$\Delta \log$ GDP squared & $\begin{array}{l}-.265 \\
(.163)\end{array}$ & $\begin{array}{l}-.252 \\
(.217)\end{array}$ & $\begin{array}{l}-.222 \\
(.156)\end{array}$ & $\begin{array}{l}-.243 \\
(.217)\end{array}$ \\
\hline Lag log GDP squared & $\begin{array}{l}.003 \\
(.058)\end{array}$ & $\begin{array}{r}.023 \\
(.076)\end{array}$ & $\begin{array}{l}-.086^{*} \\
(.052)\end{array}$ & $\begin{array}{l}.015 \\
(.076)\end{array}$ \\
\hline$\Delta$ democracy & $\begin{array}{c}-.023^{* *} \\
(.011)\end{array}$ & $\begin{array}{l}-.015 \\
(.013)\end{array}$ & $\begin{array}{c}-.022^{* *} \\
(.011)\end{array}$ & $\begin{array}{l}-.014 \\
(.013)\end{array}$ \\
\hline Lag democracy & $\begin{array}{c}-.035^{* * * *} \\
(.010)\end{array}$ & $\begin{array}{c}-.027 * * \\
(.013)\end{array}$ & $\begin{array}{c}-.046 * * * \\
(.012)\end{array}$ & $\begin{array}{c}-.025^{* *} \\
(.013)\end{array}$ \\
\hline$\Delta$ democracy squared & $\begin{array}{c}.007 * * * \\
(.002)\end{array}$ & $\begin{array}{l}.007 * * * \\
(.003)\end{array}$ & $\begin{array}{c}.007 * * * \\
(.002)\end{array}$ & $\begin{array}{c}.007 * * * \\
(.003)\end{array}$ \\
\hline $\begin{array}{l}\text { Lag democracy } \\
\text { squared }\end{array}$ & $\begin{array}{l}.004^{* *} \\
(.002)\end{array}$ & $\begin{array}{l}.004^{*} \\
(.002)\end{array}$ & $\begin{array}{l}.005^{* *} \\
(.002)\end{array}$ & $\begin{array}{l}.004^{*} \\
(.002)\end{array}$ \\
\hline$\Delta$ communist & $\begin{array}{l}-.379 \\
(.436)\end{array}$ & $\begin{array}{l}-.459 \\
(.517)\end{array}$ & $\begin{array}{l}-.272 \\
(.439)\end{array}$ & $\begin{array}{l}-.384 \\
(.518)\end{array}$ \\
\hline Lag communist & $\begin{array}{c}-1.632^{* * *} \\
(.382)\end{array}$ & $\begin{array}{c}-1.773^{* * *} \\
(.476)\end{array}$ & $\begin{array}{c}-2.033^{* * *} \\
(.471)\end{array}$ & $\begin{array}{c}-1.649 * * * \\
(.474)\end{array}$ \\
\hline$\Delta$ population & $\begin{array}{l}1.009 \\
(1.419)\end{array}$ & $\begin{array}{c}.741 \\
(1.632)\end{array}$ & $\begin{array}{l}1.354 \\
(1.327)\end{array}$ & $\begin{array}{c}.798 \\
(1.635)\end{array}$ \\
\hline Lag population & $\begin{array}{c}.221 \\
(.322)\end{array}$ & $\begin{array}{l}.313 \\
(.405)\end{array}$ & $\begin{array}{l}.192 \\
(.299)\end{array}$ & $\begin{array}{l}.304 \\
(.406)\end{array}$ \\
\hline$\Delta$ openness & $\begin{array}{c}.003 \\
(.002)\end{array}$ & $\begin{array}{c}.002 \\
(.003)\end{array}$ & $\begin{array}{c}.003 \\
(.002)\end{array}$ & $\begin{array}{l}.002 \\
(.003)\end{array}$ \\
\hline Lag openness & $\begin{array}{l}-.001 \\
(.003)\end{array}$ & $\begin{array}{l}-.002 \\
(.003)\end{array}$ & $\begin{array}{l}-.000 \\
(.003)\end{array}$ & $\begin{array}{l}-.002 \\
(.003)\end{array}$ \\
\hline$\Delta$ social security rights & $\begin{array}{l}.295 \\
(.216)\end{array}$ & $\begin{array}{l}.399 \\
(.268)\end{array}$ & & \\
\hline $\begin{array}{l}\text { Lag social security } \\
\text { rights }\end{array}$ & $\begin{array}{l}.206 \\
(.162)\end{array}$ & $\begin{array}{l}.309 \\
(.202)\end{array}$ & & \\
\hline$\Delta$ safety rights (just) & & & $\begin{array}{l}.107 \\
.(239)\end{array}$ & $\begin{array}{l}.259 \\
(.275)\end{array}$ \\
\hline Lag safety rights (just) & & & $\begin{array}{l}-.201 \\
(.231)\end{array}$ & $\begin{array}{l}-.027 \\
(.209)\end{array}$ \\
\hline Period fixed effects & Yes & Yes & Yes & Yes \\
\hline Observations & 3495 & 2475 & 3505 & 2473 \\
\hline Countries & 139 & 126 & 139 & 125 \\
\hline $\mathrm{R}$ squared within & .139 & .156 & .177 & .155 \\
\hline $\mathrm{R}$ squared between & .001 & .000 & .003 & .000 \\
\hline F statistic & 8.0 & 6.30 & 10.62 & 6.25 \\
\hline
\end{tabular}

Note: $* * *(* *)[*]$ denote significance at $\mathrm{p}<.01(\mathrm{p}<.05)[\mathrm{p}<.10]$. All estimates are FGLS with country fixed effects. 
Table 6b. Main results, net income inequality, five-year periods

\begin{tabular}{|c|c|c|c|c|}
\hline & $\begin{array}{c}\text { All observations } \\
1\end{array}$ & $\begin{array}{l}\text { Below USD } 14,000 \\
2\end{array}$ & $\begin{array}{c}\text { All observations } \\
3\end{array}$ & $\begin{array}{l}\text { Below USD } 14,000 \\
4\end{array}$ \\
\hline & \multicolumn{4}{|c|}{ Full baseline specification included } \\
\hline Lagged inequality & $\begin{array}{c}-1.095^{* * *} \\
(.016)\end{array}$ & $\begin{array}{c}-1.095^{* * *} \\
(.019)\end{array}$ & $\begin{array}{c}-1.095^{* * *} \\
(.016)\end{array}$ & $\begin{array}{c}-1.095^{* * *} \\
(.019)\end{array}$ \\
\hline$\Delta$ safety rights & $\begin{array}{c}.043 \\
(.182)\end{array}$ & $\begin{array}{r}.072 \\
(.224)\end{array}$ & & \\
\hline Lag safety rights & $\begin{array}{l}.444^{*} \\
(.229)\end{array}$ & $\begin{array}{l}.489 * \\
(.286)\end{array}$ & & \\
\hline$\Delta$ safety rights (just) & & & $\begin{array}{l}-.009 \\
(.226)\end{array}$ & $\begin{array}{l}-.004 \\
(.257)\end{array}$ \\
\hline Lag safety rights (just) & & & $\begin{array}{l}.156 \\
(.247)\end{array}$ & $\begin{array}{l}.161 \\
(.285)\end{array}$ \\
\hline Period fixed effects & Yes & Yes & Yes & Yes \\
\hline Observations & 2940 & 1999 & 2940 & 1999 \\
\hline Countries & 132 & 109 & 132 & 109 \\
\hline $\mathrm{R}$ squared within & .635 & .646 & .635 & .646 \\
\hline $\mathrm{R}$ squared between & .004 & .001 & .004 & .001 \\
\hline F statistic & 75.87 & 52.94 & 75.71 & 52.84 \\
\hline
\end{tabular}

Note: ${ }^{* * *}(* *)\left[{ }^{*}\right]$ denote significance at $\mathrm{p}<.01(\mathrm{p}<.05)[\mathrm{p}<.10]$. All estimates are FGLS with country fixed effects. All standard errors are corrected for an AR 1 disturbance since five-year periods are overlapping and therefore correlated by construction. 
Table 6c. Main results, market income inequality, annual observations

\begin{tabular}{|c|c|c|c|c|}
\hline & $\begin{array}{c}\text { All observations } \\
1 \\
\end{array}$ & $\begin{array}{c}\text { Below USD } 14,000 \\
2\end{array}$ & $\begin{array}{c}\text { All observations } \\
3 \\
\end{array}$ & $\begin{array}{c}\text { Below USD } 14,000 \\
4\end{array}$ \\
\hline & \multicolumn{4}{|c|}{ Full baseline specification included } \\
\hline Lagged inequality & $\begin{array}{c}-.166^{* * *} \\
(.009)\end{array}$ & $\begin{array}{l}-.258^{* * *} \\
(.014)\end{array}$ & $\begin{array}{c}-.165^{* * *} \\
(.009)\end{array}$ & $\begin{array}{c}-.260 * * * \\
(.014)\end{array}$ \\
\hline$\Delta$ safety rights & $\begin{array}{c}.053 \\
(.307)\end{array}$ & $\begin{array}{c}.351 \\
(.344)\end{array}$ & & \\
\hline Lag safety rights & $\begin{array}{l}.477^{* *} \\
(.216)\end{array}$ & $\begin{array}{l}.684 * * \\
(.315)\end{array}$ & & \\
\hline$\Delta$ safety rights (just) & & & $\begin{array}{r}.112 \\
(.342)\end{array}$ & $\begin{array}{c}.230 \\
(.365)\end{array}$ \\
\hline Lag safety rights (just) & & & $\begin{array}{c}.056 \\
(.245)\end{array}$ & $\begin{array}{c}.573 \\
(.394)\end{array}$ \\
\hline Period fixed effects & Yes & Yes & Yes & Yes \\
\hline Observations & 3431 & 2401 & 3431 & 2396 \\
\hline Countries & 139 & 126 & 139 & 124 \\
\hline $\mathrm{R}$ squared within & .122 & .176 & .120 & .175 \\
\hline $\mathrm{R}$ squared between & .003 & .001 & .005 & .001 \\
\hline F statistic & 6.68 & 7.02 & 6.58 & 7.19 \\
\hline
\end{tabular}


Table 6d. Main results, market income inequality, five-year periods

\begin{tabular}{|c|c|c|c|c|}
\hline & $\begin{array}{c}\text { All observations } \\
1\end{array}$ & $\begin{array}{c}\text { Below USD } 14,000 \\
2\end{array}$ & $\begin{array}{c}\text { All observations } \\
3 \\
\end{array}$ & $\begin{array}{c}\text { Below USD } 14,000 \\
4\end{array}$ \\
\hline & \multicolumn{4}{|c|}{ Full baseline specification included } \\
\hline Lagged inequality & $\begin{array}{c}-1.085^{* * *} \\
(.017)\end{array}$ & $\begin{array}{c}-1.063 * * * \\
(.021)\end{array}$ & $\begin{array}{c}-1.085^{* * *} \\
(.017)\end{array}$ & $\begin{array}{c}-1.064 * * * \\
(.021)\end{array}$ \\
\hline$\Delta$ safety rights & $\begin{array}{l}-.314 \\
(.255)\end{array}$ & $\begin{array}{l}-.136 \\
(.289)\end{array}$ & & \\
\hline Lag safety rights & $\begin{array}{l}.149 \\
(.312)\end{array}$ & $\begin{array}{l}.150 \\
(.356)\end{array}$ & & \\
\hline$\Delta$ safety rights (just) & & & $\begin{array}{l}-.304 \\
(.304)\end{array}$ & $\begin{array}{l}-.277 \\
(.315)\end{array}$ \\
\hline Lag safety rights (just) & & & $\begin{array}{l}-.029 \\
(.331)\end{array}$ & $\begin{array}{l}.052 \\
(.349)\end{array}$ \\
\hline Period fixed effects & Yes & Yes & Yes & Yes \\
\hline Observations & 2876 & 1935 & 2876 & 1935 \\
\hline Countries & 131 & 108 & 131 & 108 \\
\hline $\mathrm{R}$ squared within & .617 & .619 & .617 & .619 \\
\hline $\mathrm{R}$ squared between & .019 & .018 & .019 & .018 \\
\hline F statistic & 68.51 & 45.48 & 68.49 & 45.51 \\
\hline
\end{tabular}

Note: $* * *(* *)[*]$ denote significance at $\mathrm{p}<.01(\mathrm{p}<.05)[\mathrm{p}<.10]$. All estimates are FGLS with country fixed effects. All standard errors are corrected for an AR 1 disturbance since five-year periods are overlapping and therefore correlated by construction. 
Table 7. Main results, Child mortality, five-year periods

\begin{tabular}{|c|c|c|c|c|}
\hline & $\begin{array}{c}\text { All observations } \\
1 \\
\end{array}$ & $\begin{array}{c}\text { Below USD } 14,000 \\
2 \\
\end{array}$ & $\begin{array}{c}\text { All observations } \\
3 \\
\end{array}$ & $\begin{array}{c}\text { Below USD } 14,000 \\
4\end{array}$ \\
\hline Lagged Child Mortality & $\begin{array}{c}-.494 * * * \\
(.044)\end{array}$ & $\begin{array}{c}-.534 * * * \\
(.048)\end{array}$ & $\begin{array}{c}-.495^{* * *} \\
(.044)\end{array}$ & $\begin{array}{c}-.548^{* * *} \\
(.048)\end{array}$ \\
\hline$\Delta$ health rights & $\begin{array}{l}-.889 \\
(2.366)\end{array}$ & $\begin{array}{c}2.381 \\
(2.653)\end{array}$ & & \\
\hline Lag health rights & $\begin{array}{l}-1.615 \\
(3.067)\end{array}$ & $\begin{array}{c}4.069 \\
(3.573)\end{array}$ & & \\
\hline$\Delta$ health rights (just) & & & $\begin{array}{l}4.351 \\
(2.873)\end{array}$ & $\begin{array}{l}7.101 * * \\
(2.955)\end{array}$ \\
\hline Lag health rights (just) & & & $\begin{array}{c}1.807 \\
(3.413)\end{array}$ & $\begin{array}{c}4.12 \\
(3.563)\end{array}$ \\
\hline Period fixed effects & Yes & Yes & Yes & Yes \\
\hline Observations & 444 & 329 & 444 & 329 \\
\hline Countries & 156 & 120 & 156 & 120 \\
\hline $\mathrm{R}$ squared within & .489 & .620 & .494 & .6305 \\
\hline $\mathrm{R}$ squared between & .151 & .045 & .140 & .045 \\
\hline F statistic & 16.28 & 19.74 & 16.62 & 20.59 \\
\hline
\end{tabular}

Note: ${ }^{* *}(* *)[*]$ denote significance at $\mathrm{p}<.01(\mathrm{p}<.05)[\mathrm{p}<.10]$. All estimates are FGLS with country fixed effects. All

standard errors are corrected for an AR 1 disturbance since five-year periods are overlapping and therefore correlated by construction. 
Table 8a. Main results, government expenditures, annual observations

\begin{tabular}{|c|c|c|c|c|}
\hline & $\begin{array}{c}\text { All observations } \\
1 \\
\end{array}$ & $\begin{array}{c}\text { Below USD } 14,000 \\
2\end{array}$ & $\begin{array}{c}\text { All observations } \\
3 \\
\end{array}$ & $\begin{array}{c}\text { Below USD } 14,000 \\
4\end{array}$ \\
\hline Lagged government & $-.211 * * *$ & $-.226 * * *$ & $-.210 * * *$ & $-.226 * * *$ \\
\hline expenditures & $(.008)$ & $(.009)$ & $(.008)$ & $(.009)$ \\
\hline \multirow[t]{2}{*}{$\Delta$ age dependency } & .236 & .204 & .239 & .229 \\
\hline & $(.177)$ & $(.262)$ & $(.178)$ & $(.265)$ \\
\hline \multirow{2}{*}{ Lag age dependency } & .014 & .043 & .011 & .033 \\
\hline & $(.023)$ & $(.040)$ & $(.023)$ & $(.041)$ \\
\hline \multirow[t]{2}{*}{$\Delta \log$ GDP per capita } & $-3.549 * * *$ & $-3.379 * * *$ & $-3.562^{* * *}$ & $-3.405^{* * *}$ \\
\hline & $(.333)$ & $(.385)$ & $(.334)$ & $(.388)$ \\
\hline \multirow{2}{*}{$\begin{array}{l}\text { Lag log GDP per } \\
\text { capita }\end{array}$} & -.122 & .022 & -.124 & .014 \\
\hline & $(.098)$ & $(.117)$ & $(.098)$ & $(.120)$ \\
\hline \multirow[t]{2}{*}{$\Delta$ democracy } & $.044 * * *$ & $.042 * * *$ & $.046^{* * *}$ & $.044 * * *$ \\
\hline & $(.012)$ & $(.013)$ & $(.012)$ & $(.013)$ \\
\hline \multirow[t]{2}{*}{ Lag democracy } & -.001 & -.004 & .003 & -.000 \\
\hline & $(.007)$ & $(.008)$ & $(.007)$ & $(.008)$ \\
\hline \multirow[t]{2}{*}{$\Delta$ communist } & .515 & .554 & .503 & .477 \\
\hline & $(.438)$ & $(.492)$ & $(.438)$ & $(.512)$ \\
\hline \multirow[t]{2}{*}{ Lag communist } & $-.399 *$ & $-.439 *$ & $-.392^{*}$ & -.431 \\
\hline & $(.229)$ & $(.265)$ & $(.231)$ & $(.268)$ \\
\hline \multirow[t]{2}{*}{$\Delta$ population } & $-4.682^{* * *}$ & $-6.165^{* * *}$ & $-4.676^{* * *}$ & $-6.232^{* * *}$ \\
\hline & (1.198) & $(1.654)$ & $(1.199)$ & $(1.672)$ \\
\hline \multirow[t]{2}{*}{ Lag population } & $-.410^{*}$ & -.315 & -.327 & -.324 \\
\hline & $(.249)$ & $(.345)$ & $(.243)$ & $(.358)$ \\
\hline \multirow[t]{2}{*}{$\Delta$ openness } & $.006^{* * *}$ & $.007 * * *$ & $.006^{* * *}$ & $.007 * * *$ \\
\hline & $(.002)$ & $(.002)$ & $(.002)$ & $(.002)$ \\
\hline \multirow[t]{2}{*}{ Lag openness } & $-.003^{*}$ & $-.003^{*}$ & $-.003^{*}$ & $-.003^{*}$ \\
\hline & $(.001)$ & $(.002)$ & $(.001)$ & $(.002)$ \\
\hline \multirow[t]{2}{*}{$\Delta$ total rights } & -.037 & -.009 & & \\
\hline & $(.083)$ & $(.099)$ & & \\
\hline \multirow[t]{2}{*}{ Lag total rights } & $.100 * * *$ & $.109 * *$ & & \\
\hline & $(.038)$ & $(.047)$ & & \\
\hline \multirow[t]{2}{*}{$\Delta$ total rights (just) } & & & $-.174 *$ & -.172 \\
\hline & & & $(.105)$ & $(.117)$ \\
\hline \multirow[t]{2}{*}{ Lag total rights (just) } & & & -.007 & -.021 \\
\hline & & & $(.048)$ & $(.054)$ \\
\hline Period fixed effects & Yes & Yes & Yes & Yes \\
\hline Observations & 6230 & 4899 & 6230 & 4869 \\
\hline Countries & 159 & 147 & 159 & 141 \\
\hline $\mathrm{R}$ squared within & .139 & .143 & .139 & .144 \\
\hline $\mathrm{R}$ squared between & .014 & 0.92 & .117 & .095 \\
\hline F statistic & 15.71 & 12.44 & 15.48 & 12.46 \\
\hline
\end{tabular}

Note: $* * *(* *)[*]$ denote significance at $\mathrm{p}<.01(\mathrm{p}<.05)[\mathrm{p}<.10]$. All estimates are FGLS with country fixed effects. 
Table 8b. Main results, government expenditures, five-year periods

\begin{tabular}{|c|c|c|c|c|}
\hline & $\begin{array}{c}\text { All observations } \\
1\end{array}$ & $\begin{array}{c}\text { Below USD } 14,000 \\
2\end{array}$ & $\begin{array}{c}\text { All observations } \\
3\end{array}$ & $\begin{array}{c}\text { Below USD } 14,000 \\
4\end{array}$ \\
\hline & \multicolumn{4}{|c|}{ Full baseline specification included } \\
\hline Lagged government & $-.924 * * *$ & $-.919 * * *$ & $-.920 * * *$ & $-.921 * * *$ \\
\hline expenditures & $(.013)$ & $(.015)$ & $(.013)$ & $(.016)$ \\
\hline \multirow[t]{2}{*}{$\Delta$ total rights } & -.031 & .000 & & \\
\hline & $(.083)$ & $(.099)$ & & \\
\hline \multirow{2}{*}{ Lag total rights } & .073 & .095 & & \\
\hline & $(.111)$ & $(.133)$ & & \\
\hline \multirow[t]{2}{*}{$\Delta$ total rights (just) } & & & $-.288^{* *}$ & $-.298 * *$ \\
\hline & & & $(.112)$ & $(.125)$ \\
\hline \multirow[t]{2}{*}{ Lag total rights (just) } & & & $-.245^{*}$ & $-.268^{*}$ \\
\hline & & & $(.141)$ & $(.158)$ \\
\hline Period fixed effects & Yes & Yes & Yes & Yes \\
\hline Observations & 5576 & 4319 & 5576 & 4319 \\
\hline Countries & 157 & 137 & 157 & 137 \\
\hline $\mathrm{R}$ squared within & .492 & .483 & .491 & .484 \\
\hline $\mathrm{R}$ squared between & .063 & .022 & .063 & .022 \\
\hline F statistic & 87.90 & 65.19 & 87.54 & 65.50 \\
\hline
\end{tabular}

Note: ${ }^{* * *}(* *)[*]$ denote significance at $\mathrm{p}<.01(\mathrm{p}<.05)[\mathrm{p}<.10]$. All estimates are FGLS with country fixed effects. 
Table 9a. Main results, inflation, annual observations

\begin{tabular}{|c|c|c|c|c|}
\hline & $\begin{array}{c}\text { All observations } \\
1 \\
\end{array}$ & $\begin{array}{c}\text { Below USD } 14,000 \\
2\end{array}$ & $\begin{array}{c}\text { All observations } \\
3 \\
\end{array}$ & $\begin{array}{c}\text { Below USD } 14,000 \\
4\end{array}$ \\
\hline Lagged inflation & $\begin{array}{c}-1.099 * * * \\
(.013)\end{array}$ & $\begin{array}{c}-1.099 * * * \\
(.015)\end{array}$ & $\begin{array}{c}-1.095^{* * *} \\
(.013)\end{array}$ & $\begin{array}{c}-1.095^{* * *} \\
(.015)\end{array}$ \\
\hline$\Delta$ age dependency & $\begin{array}{l}.248 \\
(.561)\end{array}$ & $\begin{array}{l}.556 \\
(.849)\end{array}$ & $\begin{array}{l}.187 \\
(.561)\end{array}$ & $\begin{array}{l}.459 \\
(.850)\end{array}$ \\
\hline Lag age dependency & $\begin{array}{l}.025 \\
(.068)\end{array}$ & $\begin{array}{l}.139 \\
(.124)\end{array}$ & $\begin{array}{l}.040 \\
(.083)\end{array}$ & $\begin{array}{l}.070 \\
(.122)\end{array}$ \\
\hline$\Delta \log$ GDP per capita & $\begin{array}{c}-5.209 * * * \\
(.889)\end{array}$ & $\begin{array}{c}-5.666 * * * \\
(1.053)\end{array}$ & $\begin{array}{c}-5.221 * * * \\
(.891)\end{array}$ & $\begin{array}{c}-5.618^{* * *} \\
(1.059)\end{array}$ \\
\hline $\begin{array}{l}\text { Lag log GDP per } \\
\text { capita }\end{array}$ & $\begin{array}{c}-.811 * * * \\
(.294)\end{array}$ & $\begin{array}{c}-.973 * * * \\
(.361)\end{array}$ & $\begin{array}{c}-.723^{* *} \\
(.312)\end{array}$ & $\begin{array}{c}-.937 * * \\
(.368)\end{array}$ \\
\hline$\Delta$ democracy & $\begin{array}{l}.054 * \\
(.031)\end{array}$ & $\begin{array}{r}.057 \\
(.036)\end{array}$ & $\begin{array}{l}.052 * \\
(.031)\end{array}$ & $\begin{array}{l}.054 \\
(.036)\end{array}$ \\
\hline Lag democracy & $\begin{array}{l}.041^{*} \\
(.022)\end{array}$ & $\begin{array}{l}.053 * * \\
(.027)\end{array}$ & $\begin{array}{l}.045^{* *} \\
(.022)\end{array}$ & $\begin{array}{l}.052^{*} \\
(.027)\end{array}$ \\
\hline$\Delta$ communist & $\begin{array}{c}1.219 \\
(1.308)\end{array}$ & $\begin{array}{c}1.401 \\
(1.493)\end{array}$ & $\begin{array}{c}1.196 \\
(1.309)\end{array}$ & $\begin{array}{c}1.384 \\
(1.497)\end{array}$ \\
\hline Lag communist & $\begin{array}{l}-.093 \\
(.736)\end{array}$ & $\begin{array}{l}-.056 \\
(.866)\end{array}$ & $\begin{array}{l}-.051 \\
(.735)\end{array}$ & $\begin{array}{l}-.026 \\
(.866)\end{array}$ \\
\hline$\Delta$ population & $\begin{array}{l}-2.564 \\
(3.182)\end{array}$ & $\begin{array}{l}-3.581 \\
(4.458)\end{array}$ & $\begin{array}{l}-2.581 \\
(3.183)\end{array}$ & $\begin{array}{l}-3.626 \\
(4.499)\end{array}$ \\
\hline Lag population & $\begin{array}{c}.039 \\
(.644)\end{array}$ & $\begin{array}{c}.785 \\
(.883)\end{array}$ & $\begin{array}{c}.355 \\
(.919)\end{array}$ & $\begin{array}{c}.281 \\
(.831)\end{array}$ \\
\hline$\Delta$ openness & $\begin{array}{c}.002 \\
(.006)\end{array}$ & $\begin{array}{l}.001 \\
(.007)\end{array}$ & $\begin{array}{l}.001 \\
(.006)\end{array}$ & $\begin{array}{l}.001 \\
(.007)\end{array}$ \\
\hline Lag openness & $\begin{array}{l}-.001 \\
(.004)\end{array}$ & $\begin{array}{l}-.001 \\
(.005)\end{array}$ & $\begin{array}{l}-.001 \\
(.004)\end{array}$ & $\begin{array}{l}-.002 \\
(.005)\end{array}$ \\
\hline$\Delta$ total rights & $\begin{array}{l}-.306 \\
(.218)\end{array}$ & $\begin{array}{l}-.324 \\
(.266)\end{array}$ & & \\
\hline Lag total rights & $\begin{array}{l}.233^{*} \\
(.122)\end{array}$ & $\begin{array}{l}.339 * * \\
(.154)\end{array}$ & & \\
\hline$\Delta$ total rights (just) & & & $\begin{array}{l}-.510^{*} \\
(.298)\end{array}$ & $\begin{array}{l}-.515 \\
(.339)\end{array}$ \\
\hline Lag total rights (just) & & & $\begin{array}{l}.286^{*} \\
(.153)\end{array}$ & $\begin{array}{l}.289^{*} \\
(.175)\end{array}$ \\
\hline Period fixed effects & Yes & Yes & Yes & Yes \\
\hline Observations & 6100 & 4781 & 6100 & 4758 \\
\hline Countries & 159 & 143 & 159 & 143 \\
\hline $\mathrm{R}$ squared within & .557 & .559 & .556 & .557 \\
\hline $\mathrm{R}$ squared between & .013 & .008 & .049 & .007 \\
\hline F statistic & 119.38 & 95.03 & 120.45 & 92.34 \\
\hline
\end{tabular}

Note: ${ }^{* *}(* *)[*]$ denote significance at $\mathrm{p}<.01(\mathrm{p}<.05)[\mathrm{p}<.10]$. All estimates are FGLS with country fixed effects. 
Table 9b. Main results, inflation, five-year periods

\begin{tabular}{|c|c|c|c|c|}
\hline & $\begin{array}{c}\text { All observations } \\
1\end{array}$ & $\begin{array}{c}\text { Below USD } 14,000 \\
2\end{array}$ & $\begin{array}{c}\text { All observations } \\
3\end{array}$ & $\begin{array}{c}\text { Below USD } 14,000 \\
4\end{array}$ \\
\hline & \multicolumn{4}{|c|}{ Full baseline specification included } \\
\hline Lagged government & $-1.028 * * *$ & $-1.029 * * *$ & $-1.028 * * *$ & $-1.029 * * *$ \\
\hline expenditures & $(.014)$ & $(.016)$ & $(.014)$ & $(.016)$ \\
\hline \multirow[t]{2}{*}{$\Delta$ total rights } & $.377 * *$ & $.452 * *$ & & \\
\hline & $(.147)$ & $(.181)$ & & \\
\hline \multirow[t]{2}{*}{ Lag total rights } & -.017 & .009 & & \\
\hline & $(.138)$ & $(.181)$ & & \\
\hline \multirow[t]{2}{*}{$\Delta$ total rights (just) } & & & $.724 * * *$ & $.708^{* * *}$ \\
\hline & & & $(.194)$ & $(.222)$ \\
\hline \multirow[t]{2}{*}{ Lag total rights (just) } & & & -.221 & -.231 \\
\hline & & & $(.171)$ & $(.198)$ \\
\hline Period fixed effects & Yes & Yes & Yes & Yes \\
\hline Observations & 5448 & 4192 & 5448 & 4192 \\
\hline Countries & 157 & 134 & 157 & 134 \\
\hline $\mathrm{R}$ squared within & .504 & .507 & .506 & .508 \\
\hline $\mathrm{R}$ squared between & .065 & .000 & .074 & .079 \\
\hline F statistic & 91.83 & 72.06 & 92.35 & 71.14 \\
\hline
\end{tabular}

Note: ${ }^{* * *}(* *)[*]$ denote significance at $\mathrm{p}<.01(\mathrm{p}<.05)[\mathrm{p}<.10]$. All estimates are FGLS with country fixed effects. 
Table A1a. Main results, Life expectancy, five-year periods

\begin{tabular}{|c|c|c|}
\hline & $\begin{array}{c}\text { Minimum } \\
1 \\
\end{array}$ & $\begin{array}{c}\text { Maximum } \\
2 \\
\end{array}$ \\
\hline Lagged life expectancy & $\begin{array}{c}-.142^{* * *} \\
(.005)\end{array}$ & $\begin{array}{c}-.097 * * * \\
(.005)\end{array}$ \\
\hline$\Delta$ health rights (just) & $\begin{array}{l}.012 \\
(.035)\end{array}$ & $\begin{array}{l}.035 \\
(.035)\end{array}$ \\
\hline Lag health rights (just) & $\begin{array}{l}-.071 \\
(.048)\end{array}$ & $\begin{array}{l}.009 \\
(.048)\end{array}$ \\
\hline Period fixed effects & Yes & Yes \\
\hline Observations & 4273 & 4273 \\
\hline Countries & 136 & 136 \\
\hline $\mathrm{R}$ squared within & .159 & 159 \\
\hline $\mathrm{R}$ squared between & .004 & .004 \\
\hline F statistic & 13.08 & 13.08 \\
\hline \multicolumn{3}{|c|}{$\begin{array}{l}\text { Note: } * * *(* *)[*] \text { denote significance at } \mathrm{p}<.01(\mathrm{p}<.05)[\mathrm{p}<.10] \text {. All estimates } \\
\text { standard errors are corrected for an AR } 1 \text { disturbance since five-year periods } \\
\text { construction. }\end{array}$} \\
\hline \multicolumn{3}{|c|}{ Table A1b. Main results, Life expectancy, five-year periods - infl } \\
\hline & $\begin{array}{c}\text { Minimum } \\
1\end{array}$ & $\begin{array}{l}\text { Maximum } \\
2\end{array}$ \\
\hline Lagged life expectancy & Rwanda & Portugal \\
\hline$\Delta$ health rights (just) & $\begin{array}{l}\text { El Salvador } \\
\text { Uruguay }\end{array}$ & South Africa \\
\hline Lag health rights (just) & Ukraine & Estonia \\
\hline Period fixed effects & Yes & Yes \\
\hline Observations & 4273 & 4273 \\
\hline Countries & 136 & 136 \\
\hline $\mathrm{R}$ squared within & 159 & 159 \\
\hline $\mathrm{R}$ squared between & .004 & .004 \\
\hline F statistic & 13.08 & 13.08 \\
\hline
\end{tabular}


Table A2a. Main results, Immunization, five-year periods

\begin{tabular}{|c|c|c|c|c|}
\hline & $\begin{array}{c}\text { Minimum } \\
2\end{array}$ & $\begin{array}{c}\text { Maximum } \\
2\end{array}$ & $\begin{array}{c}\text { Minimum } \\
4\end{array}$ & $\begin{array}{c}\text { Maximum } \\
4\end{array}$ \\
\hline Lagged Immunization & $\begin{array}{c}-1.018^{* * *} \\
(.015)\end{array}$ & $\begin{array}{c}-1.004 * * * \\
(.018)\end{array}$ & $\begin{array}{c}-1.020 * * * \\
(.018)\end{array}$ & $\begin{array}{c}-1.006^{* * *} \\
(.018)\end{array}$ \\
\hline$\Delta$ health rights & $\begin{array}{c}0.784 \\
(0.887)\end{array}$ & $\begin{array}{c}1.843^{*} \\
(1.051)\end{array}$ & & \\
\hline Lag health rights & $\begin{array}{c}2.144 \\
(1.219)\end{array}$ & $\begin{array}{c}4.002 * * * \\
(1.462)\end{array}$ & & \\
\hline$\Delta$ health rights (just) & & & $\begin{array}{c}1.343 \\
(1.314)\end{array}$ & $\begin{array}{c}2.931^{* *} \\
(1.314)\end{array}$ \\
\hline Lag health rights (just) & & & $\begin{array}{l}3.047^{*} \\
(1.728)\end{array}$ & $\begin{array}{c}5.340 * * * \\
(1.728)\end{array}$ \\
\hline Period fixed effects & Yes & Yes & Yes & Yes \\
\hline Observations & 2415 & 2415 & 2415 & 2415 \\
\hline Countries & 124 & 124 & 124 & 124 \\
\hline $\mathrm{R}$ squared within & .618 & .618 & .619 & .619 \\
\hline $\mathrm{R}$ squared between & .158 & .158 & .163 & .163 \\
\hline F statistic & 98.73 & 98.73 & 93.79 & 93.79 \\
\hline
\end{tabular}

Note: $* * *(* *)[*]$ denote significance at $\mathrm{p}<.01(\mathrm{p}<.05)[\mathrm{p}<.10]$. All estimates are FGLS with country fixed effects.

Table A2b. Main results, Immunization, five-year periods

\begin{tabular}{|c|c|c|c|c|}
\hline & $\begin{array}{c}\text { Minimum } \\
2\end{array}$ & $\begin{array}{c}\text { Maximum } \\
2\end{array}$ & $\begin{array}{c}\text { Minimum } \\
4\end{array}$ & $\begin{array}{c}\text { Maximum } \\
4\end{array}$ \\
\hline Lagged Immunization & $\begin{array}{c}\text { Djibouti } \\
\text { El Salvador } \\
\text { Mexico }\end{array}$ & Burundi & Mexico & Burundi \\
\hline$\Delta$ health rights & Rwanda & Congo & & \\
\hline Lag health rights & Rwanda & Congo & & \\
\hline$\Delta$ health rights (just) & & & Venezuela & Malawi \\
\hline Lag health rights (just) & & & Venezuela & Malawi \\
\hline Period fixed effects & Yes & Yes & Yes & Yes \\
\hline
\end{tabular}

Note: ${ }^{* *}(* *)\left[{ }^{*}\right]$ denote significance at $\mathrm{p}<.01(\mathrm{p}<.05)[\mathrm{p}<.10]$. All estimates are FGLS with country fixed effects. 
Table A3a. Main results, Child mortality, five-year periods

\begin{tabular}{|c|c|c|c|c|}
\hline & $\begin{array}{c}\text { Minimum } \\
2 \\
\end{array}$ & $\begin{array}{c}\text { Maximum } \\
2\end{array}$ & $\begin{array}{c}\text { Minimum } \\
4\end{array}$ & $\begin{array}{c}\text { Maximum } \\
4\end{array}$ \\
\hline Lagged Child Mortality & $\begin{array}{c}-.565^{* * *} \\
(.048)\end{array}$ & $\begin{array}{c}-.381 * * * \\
(.048)\end{array}$ & $\begin{array}{c}-.575^{* * *} \\
(.048)\end{array}$ & $\begin{array}{c}-.392 * * * \\
(.048)\end{array}$ \\
\hline$\Delta$ health rights & $\begin{array}{c}-.275 \\
(2.653)\end{array}$ & $\begin{array}{c}4.286^{* *} \\
(2.653)\end{array}$ & & \\
\hline Lag health rights & $\begin{array}{c}1.968 \\
(3.573)\end{array}$ & $\begin{array}{c}5.696 \\
(3.573)\end{array}$ & & \\
\hline$\Delta$ health rights (just) & & & $\begin{array}{l}5.541 * \\
(2.955)\end{array}$ & $\begin{array}{c}8.760 * * * \\
(2.955)\end{array}$ \\
\hline Lag health rights (just) & & & $\begin{array}{c}2.133 \\
(3.563)\end{array}$ & $\begin{array}{c}5.585 \\
(3.563)\end{array}$ \\
\hline Period fixed effects & Yes & Yes & Yes & Yes \\
\hline Observations & 329 & 329 & 329 & 329 \\
\hline Countries & 120 & 120 & 120 & 120 \\
\hline $\mathrm{R}$ squared within & .620 & .620 & .6305 & .6305 \\
\hline $\mathrm{R}$ squared between & .045 & .045 & .045 & .045 \\
\hline F statistic & 19.74 & 19.74 & 20.59 & 20.59 \\
\hline
\end{tabular}

Note: $* * *(* *)[*]$ denote significance at $\mathrm{p}<.01(\mathrm{p}<.05)[\mathrm{p}<.10]$. All estimates are FGLS with country fixed effects. All standard errors are corrected for an AR 1 disturbance since five-year periods are overlapping and therefore correlated by construction.

Table A3b. Main results, Child mortality, five-year periods

\begin{tabular}{lcccc}
\hline & Minimum & Maximum & Minimum & Maximum \\
& 1 & 2 & 3 & 4 \\
\hline & & & Niger & Rwanda \\
$\begin{array}{l}\text { Lagged child mortality } \\
\text { health rights }\end{array}$ & Niger & Rwanda & & \\
$\begin{array}{l}\text { Lag health rights } \\
\text { health rights (just) }\end{array}$ & South Africa & Niganda & & Mozambique \\
$\begin{array}{l}\text { Lag health rights (just) } \\
\text { Period fixed effects }\end{array}$ & & & South Africa & Mozambique \\
\hline
\end{tabular}


Figure 1. Differences, countries with and without ESCRs

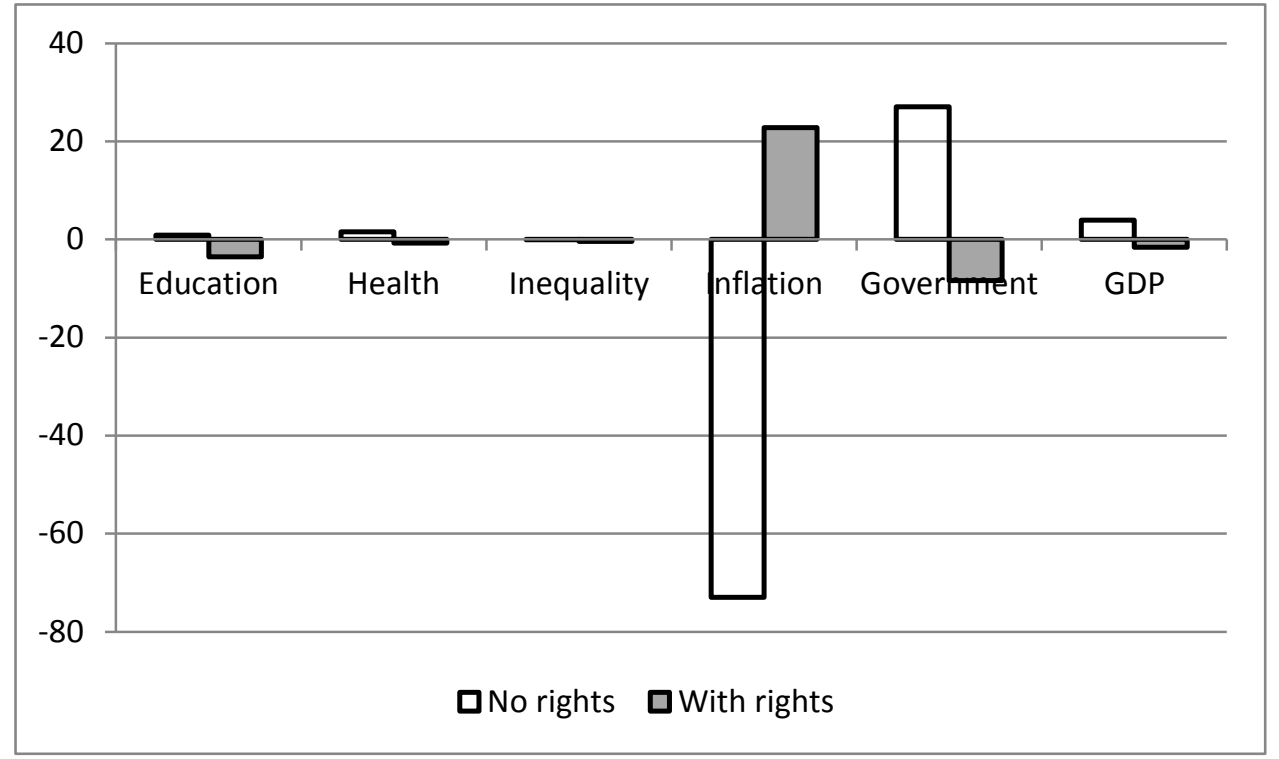


Figure 2. Overview of effects

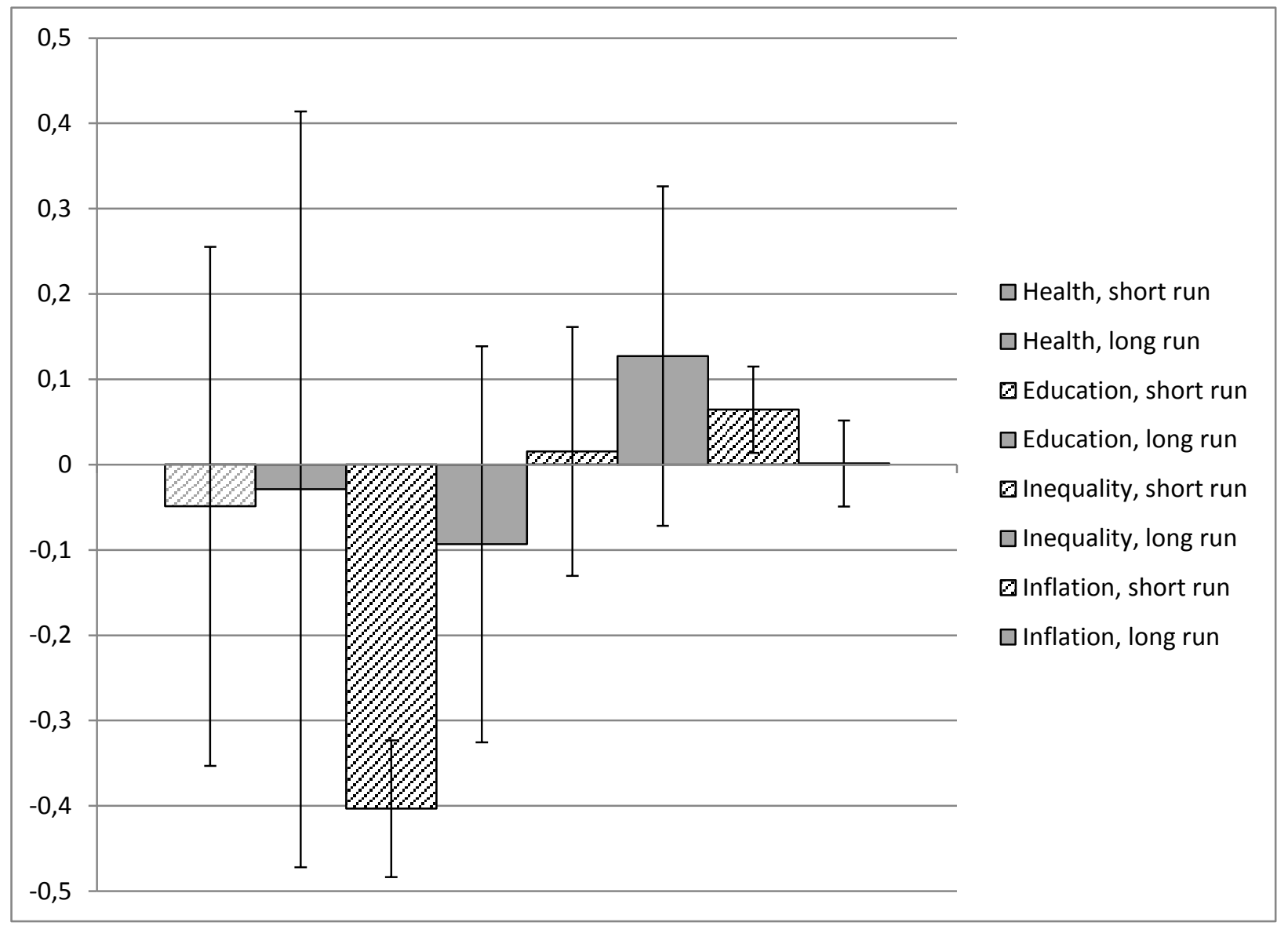




\section{Economics Working Papers}

2013-05: Niels Skipper and Rune Vejlin: Determinants of Generic vs. Brand Drug Choice: Evidence from Population-wide Danish Data

2013-06: John Kennes and John Knowles: Do Marital Prospects Dissuade Unmarried Fertility?

2013-07: John Kennes and John Knowles: Can technological change account for the sexual revolution?

2013-08: $\quad$ Christian Bjørnskov: Types of Foreign Aid

2013-09: John Kennes and Daniel le Maire: Job Heterogeneity and Coordination Frictions

2013-10: Peter Arendorf Bache and Anders Laugesen: Monotone Comparative Statics for the Industry Composition under Monopolistic Competition

2013-11: $\quad$ Anders Frederiksen and Jesper Rosenberg Hansen: Trends in Sector Switching: Evidence from Employer-Employee Data

2013-12: $\quad$ Mongoljin Batsaikhan and Norovsambuu Tumennasan: Price-Matching leads to the Cournot Outcome

2013-13: Sylvanus Kwaku Afesorgbor: Revisiting the Effectiveness of African Economic Integration. A Meta-Analytic Review and Comparative Estimation Methods

2013-14: Peter Arendorf Bache and Anders Laugesen: Trade Liberalisation and Vertical Integration

2013-15: Kaleb Girma Abreha, Valérie Smeets and Frédéric Warzynski: Coping with the Crisis: Recent Evolution in Danish Firms' - International Trade Involvement, 2000-2010

2013-16: Peter Arendorf Bache and Anders Laugesen: An Industry-Equilibrium Analysis of the LeChatelier Principle

2013-17: $\quad$ Anna Piil Damm and Christian Dustmann: Does Growing Up in a High Crime Neighborhood Affect Youth Criminal Behavior?

2013-18: Christian Bjørnskov and Jacob Mchangama: Do Social Rights Affect Social Outcomes? 